University of Nebraska - Lincoln

DigitalCommons@University of Nebraska - Lincoln

\title{
Solar Forcing of Gulf of California Climate During The Past 2000 Yr Suggested by Diatoms and Silicoflagellates
}

John A. Barron

U.S. Geological Survey, MS910, Menlo Park, CA, 94025 United States

David Bukry

U.S. Geological Survey, MS910, Menlo Park, CA, 94025 United States

Follow this and additional works at: https://digitalcommons.unl.edu/usgsstaffpub

Part of the Earth Sciences Commons

Barron, John A. and Bukry, David, "Solar Forcing of Gulf of California Climate During The Past $2000 \mathrm{Yr}$ Suggested by Diatoms and Silicoflagellates" (2007). USGS Staff -- Published Research. 263.

https://digitalcommons.unl.edu/usgsstaffpub/263

This Article is brought to you for free and open access by the US Geological Survey at DigitalCommons@University of Nebraska - Lincoln. It has been accepted for inclusion in USGS Staff -- Published Research by an authorized administrator of DigitalCommons@University of Nebraska - Lincoln. 


\title{
Solar forcing of Gulf of California climate during the past $2000 \mathrm{yr}$ suggested by diatoms and silicoflagellates
}

\author{
John A. Barron*, David Bukry \\ U.S. Geological Survey, MS910, Menlo Park, CA, 94025 United States
}

Received 20 April 2006; received in revised form 3 August 2006; accepted 4 August 2006

\begin{abstract}
High-resolution records of the past $2000 \mathrm{yr}$ are compared in a north-south transect $\left(28^{\circ} \mathrm{N}\right.$ to $\left.24^{\circ} \mathrm{N}\right)$ of three cores from the eastern slopes of the Guaymas, Carmen, and Pescadero Basins of the Gulf of California (hereafter referred to as the "Gulf"). Evenly-spaced samples from the varved sediments in each core allow sample resolution ranging from $\sim 16$ to $\sim 37 \mathrm{yr}$.

Diatoms and silicoflagellates capture the seasonal variation between a late fall to early spring period of high biosiliceous productivity, that is driven by northwest winds, and a summer period of warmer, more stratified waters during which these winds slacken and/or reverse direction (monsoonal flow). As these winds decrease, tropical waters enter the Gulf and spread northward. Individual samples represent a composite of 7 to $23 \mathrm{yr}$ of deposition and are assumed to record the relative dominance of the winter vs. summer floral components.

Intervals of enhanced summer incursion of tropical waters, alternating with periods of increased late fall to early spring biosiliceous productivity are recorded in all three cores. Regularly spaced cycles ( 100 yr duration) of Octactis pulchra, a silicoflagellate proxy for lower SST and high productivity, and Azpeitia nodulifera, a tropical diatom, occur between $\sim$ A.D. 400 and $\sim 1700$ in the more nearshore Carmen Basin core, NH01-21 $\left(26.3^{\circ} \mathrm{N}\right)$, suggesting a possible solar influence on coastal upwelling.

Cores BAM80 E-17 $\left(27.9^{\circ} \mathrm{N}\right)$ and NH01-26 $\left(24.3^{\circ} \mathrm{N}\right)$ contain longer-duration cycles of diatoms and silicoflagellates. The early part of Medieval Climate Anomaly ( A.D. 900 to 1200) is characterized by two periods of reduced productivity (warmer SST) with an intervening high productivity (cool) interval centered at $\sim$ A.D. 1050. Reduced productivity and higher SST also characterize the record of the last $\sim 100$ to $200 \mathrm{yr}$ in these cores. Solar variability appears to be driving productivity cycles, as intervals of increased radiocarbon production (sunspot minima) correlate with intervals of enhanced productivity. It is proposed that increased winter cooling of the atmosphere above southwest U.S. during sunspot minima causes intensification of the northwest winds that blow down the Gulf during the late fall to early spring, leading to intensified overturn of surface waters and enhanced productivity.
\end{abstract}

A new silicoflagellate species, Dictyocha franshepardii Bukry, is described and illustrated.

(C) 2006 Elsevier B.V. All rights reserved.

Keywords: Holocene; Gulf of California; Upwelling; Diatoms; Silicoflagellates; Monsoon; Medieval climate anomaly; Little Ice Age; Solar forcing; Sea surface temperature

* Corresponding author. Tel.: +1 650 3294971; fax: +1 650 3295203.

E-mail address: jbarron@usgs.gov (J.A. Barron).

\section{Introduction}

\subsection{Gulf of California climatology}

The climate of the Gulf of California region (Fig. 1) is characterized by a mid-latitude winter phase and a 


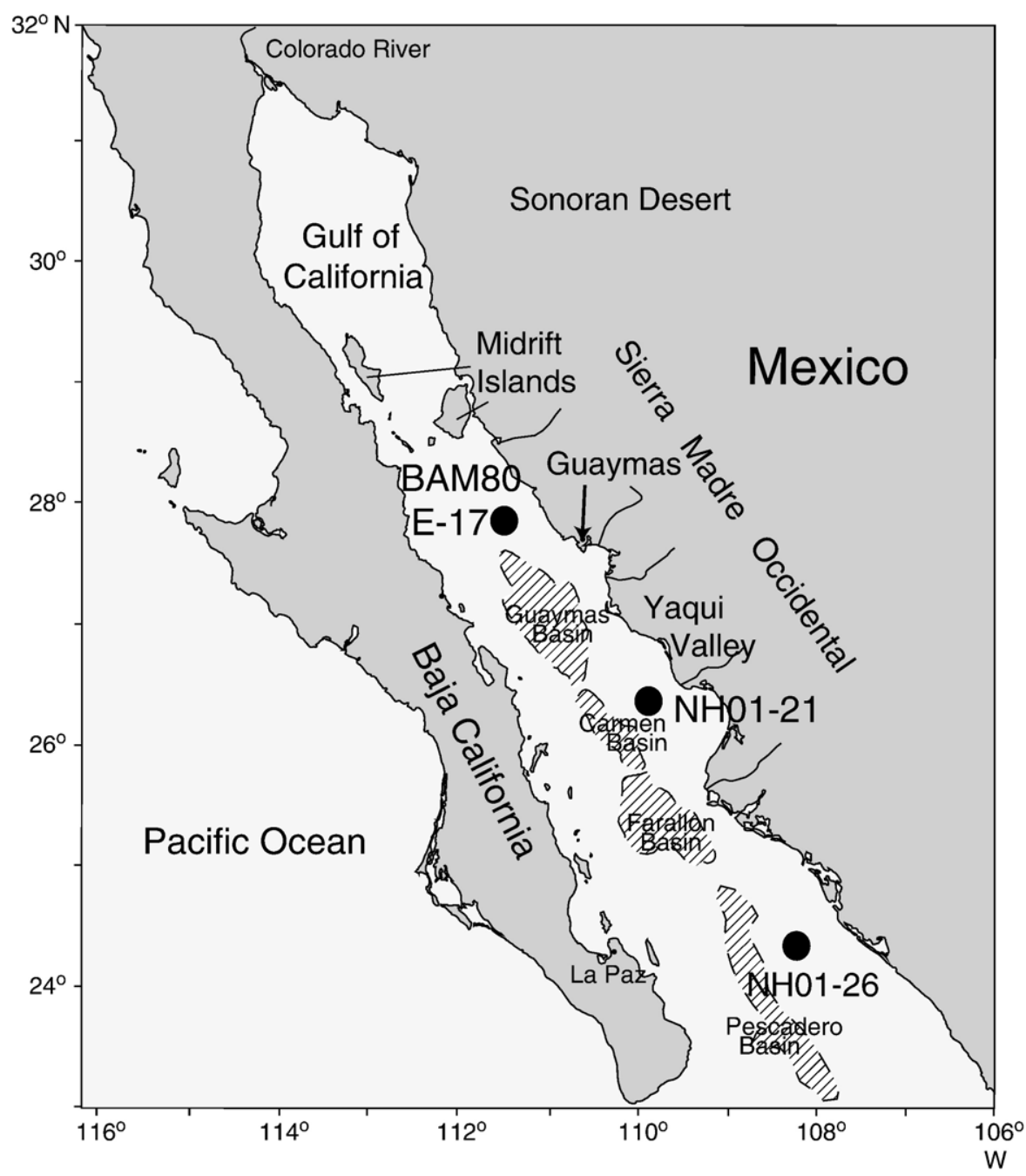

Fig. 1. Location of cores BAM80 E-17, NH01-21, and NH0-26 in the Gulf of California. Areas marked by diagonal lines represent closed basins below the $1500 \mathrm{~m}$ depth contour.

subtropical summer or monsoonal phase (Mitchell et al., 2002). During late fall to early spring (November to March), prevailing surface winds are from the northwest, blowing down the axis of the Gulf and causing an overturn of the water column. The resulting upwelling of nutrients leads to enhanced phytoplankton production, mainly on the eastern (mainland) side of the Gulf (Bandon-Dangon et al., 1991). During the winter, sea surface temperatures (SST) typically range from $\sim 18{ }^{\circ} \mathrm{C}$ in the northern Gulf to $\sim 23{ }^{\circ} \mathrm{C}$ in the southernmost Gulf (Soto-Mardones et al., 1999), a strong north-south gradient. Late spring to early fall (May to October) are characterized by a weakening of the winds and an influx of tropical surface waters from the Pacific, (SotoMardones et al., 1999; Pares-Sierra et al., 2002). Sea surface temperatures typically rise to $>28^{\circ} \mathrm{C}$ throughout the Gulf, as tropical waters move northward up the eastern (mainland) side of the Gulf (Marinone, 2003).

During El Niño events, there is a greater advection of tropical waters into the Gulf, as northwest winds slacken earlier (March) in the spring and resume later in the fall (November) (Thunell, 1998; Soto-Mardones et al., 1999).

Kahru et al. (2004) studied 6 yr (1997-2003) of satellite-generated chlorophyll $a$ data and concluded that chlorophyll $a$ concentration and phytoplankton primary production showed variability on a multitude of scales. Although the annual cycle was the dominant mode of variability, a semiannual cycle with chlorophyll maxima during the spring and fall transitions was also apparent. Douglas et al. (in press) observed that except in summer, pigment concentrations measured on the eastern side of 
the Gulf were two to three times higher than those on the west side. A north-south gradient is present in the center and the western side of the Gulf, with the highest productivity values occurring in the northern part of the Gulf and near the Midrift Islands (Fig. 1). Plankton productivity along the eastern side is largely controlled by coastal upwelling and in all seasons the gradient increases to the south.

Sediment trap studies in the Guaymas and Carmen basins (Thunell et al., 1994, 1996; Thunell, 1998) reveal that the peak flux in biogenic silica, overwhelmingly diatoms, occurs in November and December (the "fall dump" by Kemp et al., 2000), coincident with the onset of northwest winds. A second peak in diatom flux occurs during the late winter to early spring (February to March; Thunell et al., 1994), coincident with coastal upwelling, which is stronger along the mainland coast than it is off the coast of Baja California (Santamariadel-Angel et al., 1994). This late winter to early spring flux is relatively small, in comparison with that of the late fall, for which grazing by zooplankton might be responsible (Thunell, 1998).

These seasonal differences in climate and the widespread occurrence of varved sediments in the depth range between 500 and $900 \mathrm{~m}$ on the slopes of its basins make the Gulf ideal for paleoceanographic studies.

\subsection{Previous paleoceanographic studies}

Barron et al. (2004, 2005) summarized many paleoceanographic studies covering the past $15,000 \mathrm{yr}$. They concluded that the modern oceanography of the Gulf evolved after $\sim 5.4$ ky when tropical diatoms and silicoflagellates became relatively common in the central Gulf and late winter-early spring coastal upwelling became more intense on the eastern (mainland) side. Barron et al. (2005) argued that the North American Monsoon, as we know it today, did not exist prior to $~ 5.4 \mathrm{ky}$, and that EL Niño/Southern Oscillation (ENSO)-driven changes in the position of the Intertropical Convergence Zone (ITCZ) were likely responsible.

Higher resolution $(<100 \mathrm{yr}$ sample spacing) paleoceanographic studies in the Gulf have focused on determining climatic variability of the last 2000 to $300 \mathrm{yr}$ and establishing possible forcing mechanisms.

Murray (1982) studied the downcore variability of silicoflagellate assemblages in Kasten Core BAM80 E-17 $\left(27.920^{\circ} \mathrm{N}, 111.610^{\circ} \mathrm{W}, 620 \mathrm{~m}\right.$ of water depth; Fig. 1) in the eastern Guaymas Basin. He found major cycles in the relative percentages of Octactis pulchra, a silicoflagellate that he considered indicative of upwelling and high productivity, and Dictyocha messanensis (D. stapedia of
Barron et al., 2004, 2005), a silicoflagellate indicative of reduced productivity.

Schrader and Baumgartner (1983) documented decadal variations of productivity levels during the past $500 \mathrm{yr}$ in a number of Kasten cores, including BAM80 E-17, from the central Gulf of California. They used $O$. pulchra to estimate productivity with a chronology based on varve counts and silicoflagellate assemblage changes and compared their results with a tree-ring record from the Sierra Madre Occidental, concluding that drier continental conditions correlated with intervals of increased productivity (higher upwelling).

Julliet-Leclerc and Schrader (1987) used oxygen isotopes from diatom biogenic silica to infer sea surface temperature (SST) variations in the eastern Guaymas Basin in BAM80 E-17. They observed a total temperature amplitude of $\sim 8{ }^{\circ} \mathrm{C}$ over the 3000 -yr-long record with highest SST's $\left(17^{\circ} \mathrm{C}\right)$ occurring at the core top and approximately $3000 \mathrm{yr}$ ago. Julliet-Leclerc and Schrader (1987) suggested that northwestern winds (upwelling and low SST's) were at their maximum between $\sim 2000$ and 1500 yr B.P.

Goñi et al. (2001) completed high resolution (sub decadal) alkenone analysis to derive SST variability in Guaymas Basin Atlantis II 125 box core BC-43 $\left(27.9015^{\circ} \mathrm{N}, 111.656^{\circ} \mathrm{W}\right.$, water depth $\left.655 \mathrm{~m}\right)$ for the past $300 \mathrm{yr}$. They found a steady $2{ }^{\circ} \mathrm{C}$ warming of the surface waters of the central Gulf from the early 1700 s to the 1950 s, followed by a rapid apparent $1{ }^{\circ} \mathrm{C}$ cooling between the 1950s and the 1980s.

Barron et al. (2003) completed a high resolution ( 37 yr sample spacing) study of the diatom, silicoflagellate, and geochemical record of BAM80 E17 for the past $2000 \mathrm{yr}$. They observed intervals enriched in diatoms alternated $\sim$ every $200 \mathrm{yr}$ with intervals with more terrigenous material and total organic carbon (TOC) and suggested that solar forcing may have been responsible for the climatic cycles. Barron et al. (2003) noted that the record of concentration of biogenic silica in BAM80 E-17 was remarkably similar to the radiocarbon production curve. They speculated that the solar minima caused cooling of the winter atmosphere above the southwestern U.S., which caused an increase in the strength and/or duration of the late fall/winter northwest winds and led to increased biogenic productivity. These authors also observed a prolonged interval of dramatically higher SST's between $\sim 910$ and 1140 A.D. (corresponding to early part of the Medieval Climate Anomaly $\{\mathrm{MCA}\})$ that was marked by a two-fold increase (above normal background fluctuations) in the relative abundance of the tropical diatom Azpeitia nodulifera. 
Dean et al. (2004) recorded geochemical cycles in varved sediments from the Guaymas and Carmen Basins (Fig. 1) during the past $180 \mathrm{yr}$ at a 2 to 3 year sample spacing and observed 20 -yr cycles in the titanium record of the 19th century, which they related to riverine influx from the Sierra Madre in mainland Mexico. They documented a strong correlation of the titanium (Ti) cycles with the Pacific Decadal Oscillation (PDO) and suggested that riverine influx in the Gulf responded to ENSO forcing. Pacific Decadal Oscillation (PDO) is a long-lived El Niño-like pattern of Pacific climate variability (Zhang et al., 1997). As with ENSO, extremes in the PDO pattern are marked by widespread variations in Pacific Basin and North American climate that are classified as being either warm or cool, based on SST anomalies in the northeast and tropical Pacific Ocean (http://www.atmos.washington.edu/ mantua/ REPORTS/PDO/PDO_cs.htm).

Herguera et al. (2003) produced a high resolution oxygen isotope record of the planktic foraminifer Globigerina bulloides for the past $300 \mathrm{yr}$ in the southwest Gulf box core BAP96-CM. They used these data and the modern instrumental record to produce a mean record of winter SST and concluded that the period between 1700 and 1830 had cooler winters alternating with warmer ones, whereas the period since 1830 was dominated by warmer winters. These authors suggested that the variability in winter SSTs on interannual to decadal time scales seemed to be modulated by low-frequency ENSO variability.

Staines-Urias and Douglas (in press) used oxygen and carbon isotopes of planktic and benthic foraminifers in multicores NH01-15 and NH01-26 in the southern Gulf to construct a 300-yr-long history of ocean-climate changes. Their studies suggested that the period between 300 and 80 yr B.P. was characterized by higher productivity and cooler, less variable SST than the present. Staines-Urias and Douglas (in press) concluded that the lower Gulf has become warmer and/or less saline and less productive since the early 20th century, probably as a result of tropical forcing.

Douglas et al. (in press) compared high resolution records of the past $\sim 8000 \mathrm{yr}$ in varved sediments from gravity cores NH01-15 and NH01-26 from the southwest and southeast parts of the Gulf. They documented a series of depositional cycles in the biogenic record, with the strongest peaks of variability at about $150 \mathrm{yr}(144 \pm$ $18 \mathrm{yr}), 200 \mathrm{yr}(198 \pm 5 \mathrm{yr})$, and $350 \mathrm{yr}(350 \pm 40 \mathrm{yr})$. Douglas et al. (in press) noted that these periodicities were present prior to $3.2 \mathrm{ky}$, but the $350-\mathrm{yr}$ cycle dominated the latest Holocene record. They suggest that the centennial variability is related to variations in solar insolation as identified in radiocarbon fluctuations in tree rings and Beryllium-10 records.

These paleoceanographic studies demonstrate that surface water conditions in the Gulf of California have alternated at sub decadal to sub centennial time scales between cooler SST, indicative of upwelling caused by persistent northwest winds. and warmer, more oligotrophic conditions, reflecting slackening of these winds and northward penetration of Pacific tropical waters into the Gulf. These studies thus suggest that Gulf climatic cycles on varying time scales reflect differing lengths of the winter (high productivity) season $v s$. the summer (low productivity) season. Recent authors have attributed these fluctuations either to ENSO/PDO (Herguera et al., 2003; Dean et al., 2004) or to solar variability (Goñi et al., 2001; Barron et al., 2003).

The purpose of this study is to document surface water conditions in the Gulf using diatoms and silicoflagellates during the past $2000 \mathrm{yr}$. High resolution $(<100 \mathrm{yr})$ assemblage data will be compiled in a north-south transect $\left(28^{\circ} \mathrm{N}\right.$ to $\left.24^{\circ} \mathrm{N}\right)$ of 3 cores which contain varved sediment. These data will be compared to establish differences and similarities that can be used to suggest a possible forcing mechanism for Gulf climate.

\section{Materials and methods}

Kasten core BAM80 E-17 was taken by the R/V Matamoros of Oregon State University in 1980 at $27.920^{\circ} \mathrm{N}$ and $111.610^{\circ} \mathrm{W}$ in $620 \mathrm{~m}$ of water in the northern part of the central Gulf where biogenic silica production (mainly diatoms) is very high. This site is strongly influenced by coastal upwelling as well as by mixing and gyres which cause overturn of surface waters (Douglas et al., in press). BAM80 E-17 lies within sub-area 6 of Kahru et al. (2004), characterized by moderate chlorophyll variability.

Gravity core NH01-21 was collected in 2001 by the $\mathrm{R} / \mathrm{V}$ New Horizon from the eastern slope of the Carmen Basin $\left(26^{\circ} 17.39^{\prime} \mathrm{N}, 109^{\circ} 55.24^{\prime} \mathrm{W}\right.$, at a water depth of $575 \mathrm{~m})$. The site lies under a major persistent coastal upwelling cell (R. Douglas, personal comm., 2005; Douglas et al., in press) in the southern part of the central Gulf. The location of NH01-21 is within subarea 8 of Kahru et al. (2004), characterized by high amplitude chlorophyll variability.

Gravity core NH01-26 was collected in 2001 by the $\mathrm{R} / \mathrm{V}$ New Horizon from the eastern slope of the Pescadero Basin $\left(24^{\circ} 16.78^{\prime} \mathrm{N}, 108^{\circ} 11.65^{\prime} \mathrm{W}\right.$, at a water depth of $600 \mathrm{~m}$ ). The site lies in the southernmost Gulf, a little seaward (east) of the zone of coastal upwelling (Douglas et al., in press). NH01-26 is located within sub-area 11 of 
Kahru et al. (2004), where chlorophyll variability is reduced compared to that of the central Gulf.

\subsection{Age model}

Murray (1982) used varve counting to estimate the sedimentation rate of BAM80 E-17 at $230 \mathrm{~cm} / \mathrm{kyr}$, although three radiocarbon dates on benthic foraminifers suggested a sedimentation rate of $130 \mathrm{~cm} / \mathrm{kyr}$. Subsequent varve counting by Karlin (1984) yielded a sedimentation rate of $135 \mathrm{~cm} / \mathrm{kyr}$ that conforms more closely to the sedimentation rate suggested by radiocarbon dating.

Planktic foraminifers from $410 \mathrm{~cm}$ in of NH01-21 (GC1) were dated by AMS at $6375 \pm 45$ radiocarbon yr B.P. Application of a $406 \pm 34 \mathrm{yr}$ reservoir correction for the south central Gulf(Frantz et al., 2000; Regional mean for the Gulf from the Calib 5.0.1, Marine Reservoir Correction Database, http://calib.qub.ac.uk/marine) and the Calib 5.0.1 program (http://calib.qub.ac.uk/) yields a calibrated date of 6324 to 6570 yr B.P. (two sigma range), implying an average sedimentation rate of $63.6 \mathrm{~cm} / \mathrm{kyr}$.

Planktic foraminifers from $392 \mathrm{~cm}$ in NH01-26 (GC2) were dated by AMS at $8760 \pm 50$ radiocarbon yr B.P. Application of a $253 \pm 118 \mathrm{yr}$ reservoir correction for the southern Gulf (Frantz et al., 2000) and the Calib 5.0.1 program yields a calibrated date of 9341 to $9049 \mathrm{yr}$ B.P. (two sigma range), implying an average sedimentation rate of $42.6 \mathrm{~cm} / \mathrm{kyr}$ for NH01-26.

The presence of only one AMS date each in cores NH01-21 and NH01-26 limits the accuracy their age models. Low carbonate contents in the upper parts of these cores have so far frustrated efforts to obtain additional AMS dates (R. Douglas, oral comm., 2005). Other varved Gulf cores containing good AMS chronologies (JPC56, DSDP 480, BAM80 E-17), however, have near uniform sedimentation rates in their post-9 ky sequences. It therefore seems appropriate in this preliminary study to use average sedimentation rates of 63.6 and $42.6 \mathrm{~cm} / \mathrm{kyr}$, respectively, for cores NH01-21 and NH01-26.

\subsection{Sampling}

Samples were taken at 5-cm-intervals from the upper $250 \mathrm{~cm}$ of BAM80 E-17, corresponding to a sampling interval of $\sim 37 \mathrm{yr}$ (Karlin, 1984) for the sedimentation rate of $135 \mathrm{~cm} / \mathrm{kyr}$. Each sample of the varved sediment was about $1 \mathrm{~cm}$ thick, representing about $7 \mathrm{yr}$ of deposition. Samples were taken vertically across the varves and homogeneous splits were used for siliceous microfossil and geochemical studies.
Samples were taken at 1-cm-intervals from NH01-21, corresponding to a sample interval of $\sim 16 \mathrm{yr}$, assuming a constant sedimentation rate of $63.6 \mathrm{~cm} / \mathrm{kyr}$. The $\sim 1 \mathrm{~cm}$ thickness of each sample suggests that they each represent a composite of this $16 \mathrm{yr}$-long interval. It is likely that the sedimentation rate increases near the top of core NH0121-GC due to decreased compaction of the sediments.

Samples were taken every $1 \mathrm{~cm}$ from NH01-26, corresponding to a sample interval of $23 \mathrm{yr}$, assuming a constant sedimentation rate of $42.6 \mathrm{~cm} / \mathrm{kyr}$. The $\sim 1 \mathrm{~cm}$ thickness of each sample suggests that they each represent a composite of this $23 \mathrm{yr}$-long interval.

\subsection{Processing}

Samples from BAM80 E-17 were disaggregated in distilled water and then boiled in 30\% hydrogen peroxide and $37 \%$ hydrochloric acid. The acid was removed through several washings in distilled water separated by at least $4 \mathrm{~h}$ of settling and decanting of the liquid. The final sample was stored in a vial containing at least 7-10 times as much distilled water as sample. To prepare slides, the vial was shaken and a drop of the suspension was taken after 5-10 s of settling from near the top of the vial, transferred to a $30 \times 22 \mathrm{~mm}$ cover slip and allowed to dry on a warming tray overnight. Slides were then mounted in Naphrax (index of refraction=1.74).

Comparison of chemically-processed residues with residues that were merely disaggregated in distilled water revealed that diatom and silicoflagellate taxa could be readily recognized and counted without chemical processing. Samples from NH01-21 and NH01-26 were therefore not processed with chemicals but instead placed in a glass vial and covered with 7-10 times as much distilled water as sample. A disposable wooden stick was used to disaggregate the samples in the vials by stirring. To prepare slides, the vial was shaken and a drop of the suspension was taken after 5-10 s of settling from near the top of the vial, transferred to a $30 \times 22 \mathrm{~mm}$ cover slip and allowed to dry on a warming tray overnight. Slides were then mounted in Naphrax.

\subsection{Diatoms}

Following Sancetta (1995), counts of diatoms were made under the light microscope at 500×, ignoring Chaetoceros spores and Thalassionema nitzschioides that dominate the sediment assemblages and mask subtle seasonal abundance changes in less common diatom taxa. As in Barron et al. (2004, 2005), small and delicate taxa such as Fragilariopsis, Rhizosolenia, and Thalassiosira were also not tabulated so as to reduce bias 
caused by differential dissolution and differential settling of pipetted samples. Large centric diatoms demonstrating clear environmental preferences according to the sediment trap studies of Sancetta (1995; written comm., 2001), and sediment fabric studies of Pike and Kemp (1997) and Kemp et al. (2000) were counted. These included Actinocyclus curvatulus, A. octonarius, Actinoptychus spp., A. nodulifera, Coscinodiscus radiatus, Coscinodiscus spp. (mainly large-diameter forms such as C. asteromphalus, C. granii, and C. oculus-iridis), Cyclotella spp. (mainly C. littoralis), Roperia tesselata, and Stephanopyxis palmeriana. At least 200 diatoms per sample were counted using the techniques of Schrader and Gersonde (1978) in random traverses across the microscope slide at $500 \times$.

\subsection{Silicoflagellates}

Silicoflagellate slides were systematically tracked to obtain a representative count of 200 specimens per sample. Counts were typically made at $250 \times$ magnification, with $500 \times$ used for checking questionable identifications. All whole specimens and half specimens with intact apical structures were counted. Smaller fragments were not counted.

Taxa counted included those tabulated by Poelchau (1976) and Murray and Schrader (1983), although their taxonomy has been updated. Additional taxa tabulated include $D$. calida ampliata, a tropical form grouped with $D$. calida and D. aspinosa, a cosmopolitan form, grouped with D. stapedia by Poelchau (1976). Dictyocha sp. A and B of Murray and Schrader (1983) are tabulated as $D$. perlaevis, although the $D$. sp. A forms can be distinguished by their more elongate appearance, resulting in a minor axis lacking spines on the basal ring. D. messanensis of Murray and Schrader (1983) is recognized as Dictyocha stapedia. Similarly, Dictyocha epidon of Murray and Schrader (1983) is recognized as D. aculeata. Large specimens of Dictyocha with canted apical bars and slightly bowed basal ring, reminiscent of $D$. aculeata, are recorded as $D$. sp. aff. $D$. aculeata (see illustrations in Barron et al., 2005). These probably represent an endemic Gulf variant of $D$. aculeata. $O$. pulchra specimens were separated into three size categories: 1) large specimens; 2) medium specimens typically one half the size of the larger specimens; and 3) small specimens typically one fourth the size of the larger specimens.

\section{Results}

The relative abundance data for diatoms and silicoflagellates during the past $2000 \mathrm{yr}$ for the three cores,
BAM80 E-17, NH01-21, and NH01-26, are presented in Tables 1-6 of the Internet version (Science Direct).

\subsection{BAM80 E-17, north central Gulf (Figs. 2, 3)}

A. nodulifera, a tropical diatom, typically makes up less than $20 \%$ of the tabulated diatom assemblage. However, five intervals of increased relative abundance approaching or exceeding 30\% are recorded at $\sim$ A.D. 150, A.D. 350, between $\sim$ A.D. 900 and 1000 (peak "A"), between A.D. 1120 and 1150 (peak "B"), and between A.D. 1520 and 1560 (peak "C) (Fig. 2).

Cyclotella spp. (mainly C. littoralis), is a coastal diatom indicative of low production in warm, stratified, and nutrient-limited waters of the summer and early fall. Relative abundance values of Cyclotella spp. fluctuate between $\sim 10$ and 35\% in BAM80 E-17, with low values typically coinciding with high values of $A$. nodulifera.

Percentage values of Actinoptychus spp., shelfdwelling taxa that are transported downslope, range between $\sim 20$ and $40 \%$. Lower values of this shelfdwelling diatom typically correspond with intervals of higher percentages of $A$. nodulifera.

In the bottom plot of Fig. 2, the percentage of $A$. curvatulus, $C$. radiatus, and $R$. tesselata are combined to represent winter diatom production (Sancetta, 1995; Barron et al., 2004, 2005); values typically range between 20 and $30 \%$, with higher values between $\sim$ A.D. 620 and 820 and between $\sim$ A.D. 1600 and 1800 .

O. pulchra, a silicoflagellate associated with high biologic productivity (Schrader and Baumgartner, 1983; Murray and Schrader, 1983), shows strong fluctuations, between $\sim 40$ and $80 \%$ of the silicoflagellate assemblage (Fig. 3). As noted by Barron et al. (2003), there is a positive correspondence between the relative percentage changes of $O$. pulchra and $\%$ biogenic silica.

Dictyocha calida, a tropical silicoflagellate associated with the eastern equatorial Pacific (Schrader et al., 1986), varies between 0 and $12 \%$ of the silicoflagellate assemblage.

D. stapedia, a cosmopolitan silicoflagellate associated with oligotrophic conditions in the Gulf (Murray and Schrader, 1983; Schrader et al., 1986; recorded as D. messanenesis) displays trends in its relative abundance that are opposite to that of $O$. pulchra (correlation coefficient of -0.691$)$. Prior to $\sim$ A.D. 1300, D. stapedia was relatively rare, whereas after $\sim$ A.D. 1300 it became relatively more abundant with higher amplitude cycles (Fig. 3).

Dictyocha aculeata, a silicoflagellate associated with the eastern equatorial Pacific by Schrader et al. (1986) 

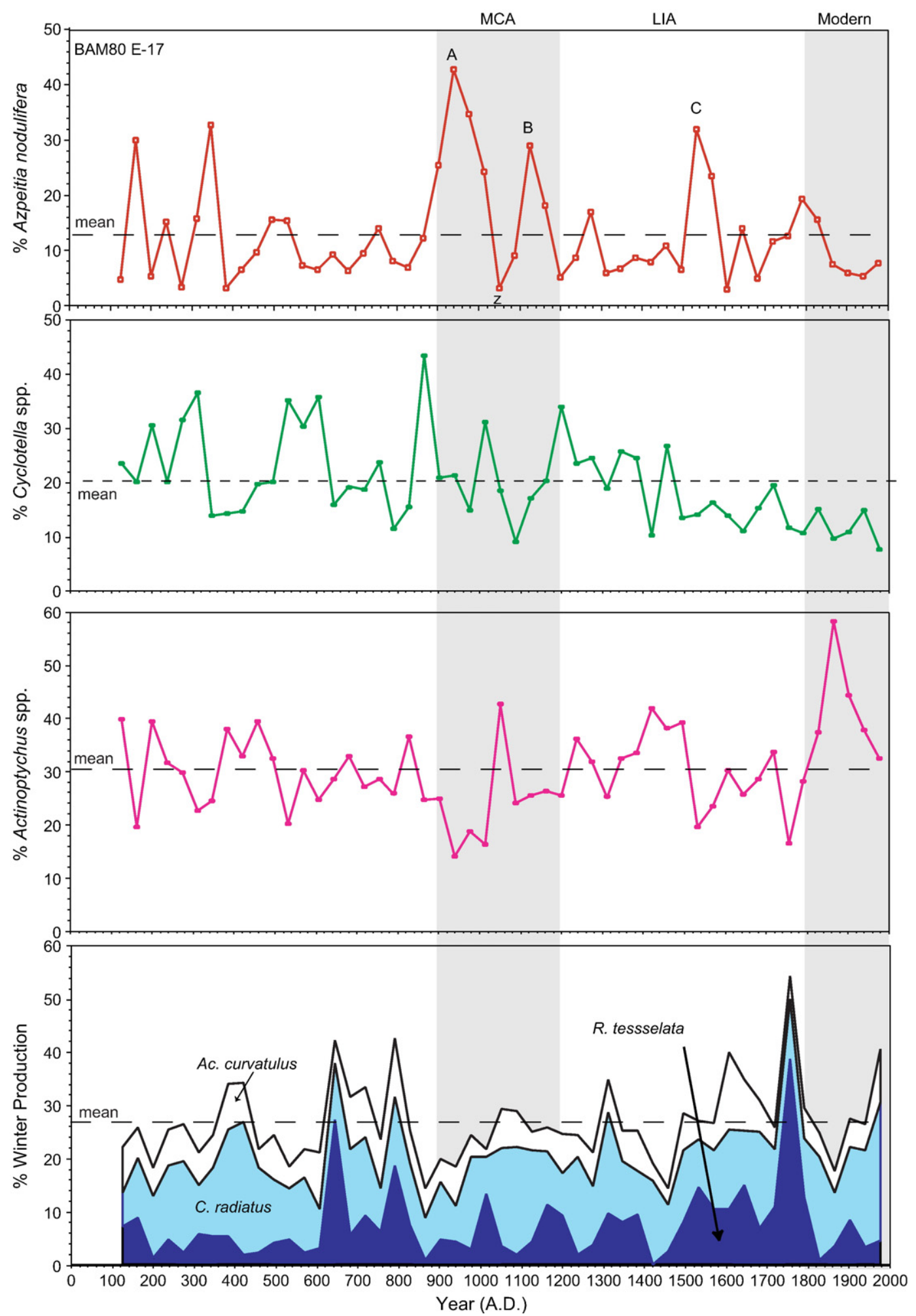

Fig. 2. Comparison of the percentages of the key diatom taxa during the past $2000 \mathrm{yr}$ in BAM80 E-17. Percentages are of selected diatom taxa, see Materials and methods. MCA, Medieval Climate Anomaly, LIA, Little Ice Age. 
(= D. epiodon of Murray and Schrader, 1983 and D. mandrai of Schrader et al., 1986) and D. sp. aff. D. aculeata, a possible Gulf variant of this taxon (Barron et al., 2005) typically compose less than $10 \%$ of the silicoflagellate assemblage. Bukry (1980) records abundant $D$. aculeata in upper Quaternary sediments of the eastern equatorial Pacific between $\sim 1^{\circ}$ and $8^{\circ} \mathrm{N}$, characterized by warm $>27{ }^{\circ} \mathrm{C}$ annual sea surface temperatures (SST), so this D. "aculeata" group may possibly be considered an indicator of tropical to subtropical open Pacific waters. Values in excess of $18 \%$ of the $D$. "aculeata" group occurred between $\sim$ A.D. 900 and 1000, between A.D. 1080 and 1140, and during the last $200 \mathrm{yr}$ (Fig. 3). All these intervals have low values of $O$. pulchra (correlation coefficient of -0.602).

\subsection{NH01-21, upwelling region, south central Gulf (Figs. 4,5)}

The most striking characteristic of the diatom record is the occurrence of regular $\sim 100$ yr-long cycles in the relative abundance record of $A$. nodulifera between $\sim$ A.D. 350 and 1750 (Fig. 4), with an amplitude of $>40 \%$ (mean 29.9\%). This contrasts with earlier (before A.D. 350) and later (after A.D. 1750) intervals, where the amplitude is less than $15 \%$. An interval of unrecovered
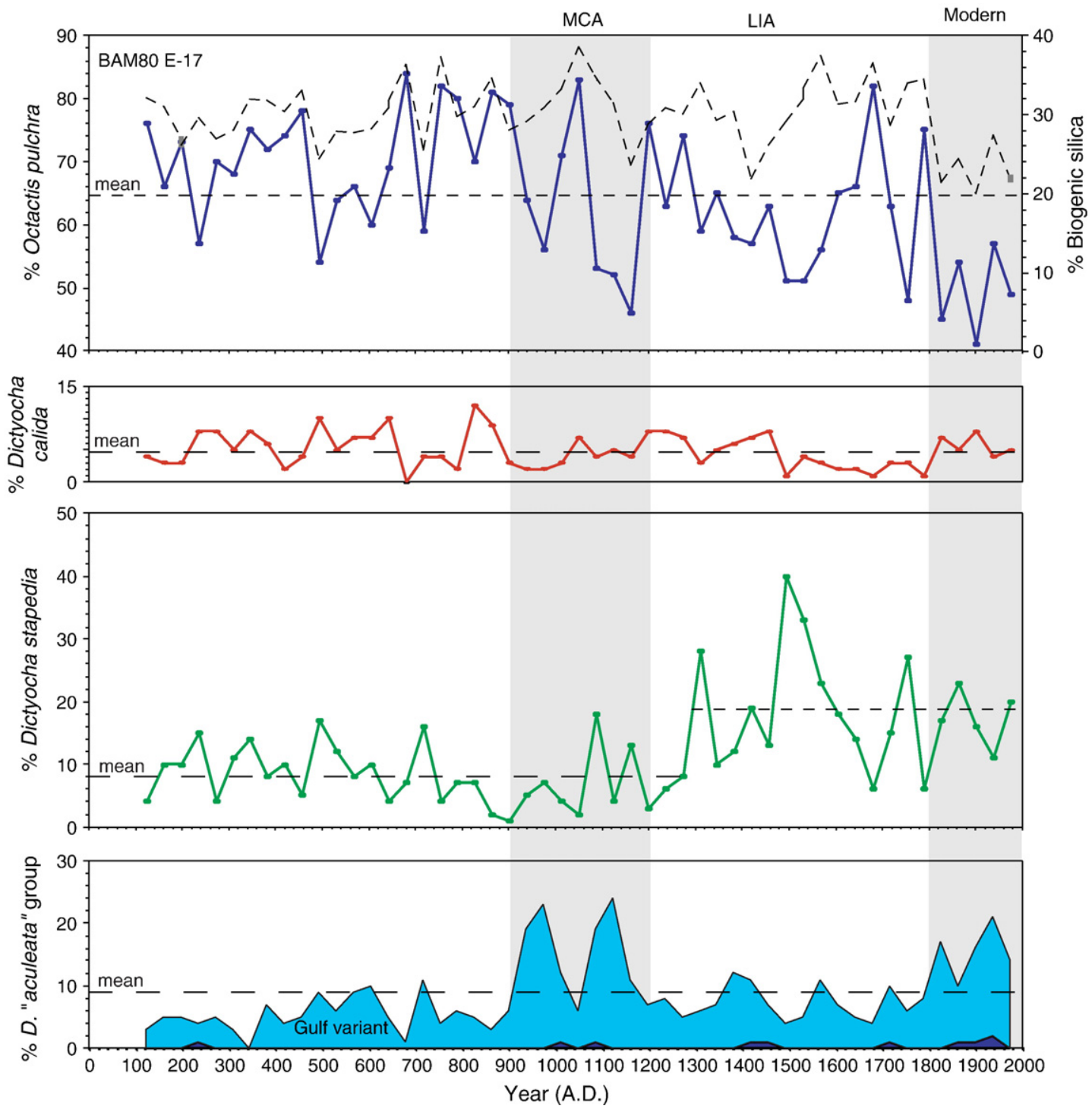

Fig. 3. Comparison of the relative contributions of key silicoflagellates during the past $2000 \mathrm{yr}$ in BAM80 E-17. Gulf variant refers to Dictyocha sp. aff. D. aculeata. Percent biogenic silica (closely-spaced dashed line) after Barron et al. (2003). 
core material is present between 17 and $21 \mathrm{~cm}$ depth in NH01-21 (R. Douglas, written comm., 2005), which might result in age estimates of NH01-21 samples below $21 \mathrm{~cm}(\sim 1647$ A.D. on Figs. 4,5) being $\sim 60 \mathrm{yr}$ too old.

Cyclotella spp. varies between $\sim 10$ and $60 \%$ (mean $36.7 \%$, standard deviation $10.1 \%$ ) with high amplitude cycles that are opposite to those of $\%$ A. nodulifera (correlation coefficient -0.779). Actinoptychus spp. also displays strong cycles with percentages typically between 10 and $30 \%$. These cycles are negatively correlated with those of $A$. nodulifera (correlation coefficient of -0.702). The winter production diatom group (A. curvatulus, $C$. radiatus, and $R$. tesselata) typically varies between 10 and $20 \%$ (Fig. 4) and is negatively correlated with those of A. nodulifera (correlation coefficient -0.652 ).

The silicoflagellate record at NH01-21 (Fig. 5) is marked by strong cycles in the percentages of $O$. pulchra, the productivity proxy, varying in a general inverse relationship with $\% D$. stapedia (Fig. 4). The percentages of $O$. pulchra range between $\sim 10$ and $70 \%$, whereas $\% D$. stapedia typically ranges between 10 and 50\%. Reduced amplitude cycles of $\% O$. pulchra of two to three sample duration ( $~ 32$ to $48 \mathrm{yr})$ alternate with increased amplitude cycles of five to seven sample duration (90 to $112 \mathrm{yr}$ ). The latter cycles ( 90 to $112 \mathrm{yr}$ ) seem to be more typical of the \% D. stapedia record, with troughs of $\%$ D. stapedia $<25 \%$ correlating with peaks of $\%$ O. pulchra $>50 \%$ of the silicoflagellate assemblage. Intervals of increased $\% O$. pulchra tend to coincide with intervals of increased relative percent abundance of the winter production diatom group. The tropical silicoflagellate, $D$. calida, typically has percentages ranging between 5 and $15 \%$, with a few peaks ranging from 20 to $30 \%$. There is a slight negative correlation $(-0.389)$ between $D$. calida with the relative abundance of the winter production diatom group. The Dictyocha "aculeata" group ranges from 0 to $10 \%$, with no obvious correlation with cycles of any of the other silicoflagellates or diatoms. Dictyocha franshepardii new sp., equivalent to Dictyocha sp. 2 of Murray and Schrader (1983), varies between $\sim 2$ and 20\% (Fig. 4), with its relative abundance peaks seeming to occur during intervals of lower $\% O$. pulchra.

\subsection{NH01-26, southernmost Gulf (Figs. 6,7)}

A. nodulifera, typically varies between $\sim 4$ and $12 \%$ of the tabulated diatom assemblage, with the exception of two peaks centered at A.D. 880 ("A") and A.D. 1100 ("B") where values exceed 22\%. (Fig. 6). These peaks are about coeval with peaks "A" and "B" of BAM80 E-17 (Fig. 2) and NH01-21 (Fig. 4) which are dated at $\sim$ A.D. 940 and 1020, respectively, in BAM80 E-17. Such a correlation suggests that as much as a $60 \mathrm{yr}$ age shift towards younger ages might be applied to the age model of NH01-26 in the vicinity of peak " $\mathrm{A}$ " in order to bring estimated ages more in line with those of BAM80 E-17.

The diatom record is dominated by Cyclotella spp. with values mostly ranging between 50 and $80 \%$ of the tabulated diatom assemblage (Fig. 6). Unlike other cores, the negative correlation of \% Cyclotella spp. and $\%$ A. nodulifera is relatively weak. Prior to $\sim$ A.D. 1250 , the winter diatom production group typically made up 5 to $16 \%$, whereas after that time, relative abundance peaks $(>24 \%)$ occurred regularly, roughly every $80 \mathrm{yr}$. There is a strong negative correlation between the winter production diatom group and $\% A$. nodulifera and \% Cyclotella spp. Actinoptychus spp. ranges between $\sim 5$ and $20 \%$ in relative abundance (Fig. 6), and exhibit poorly-defined cycles of 100 to 200 yr duration.

$D$. franshepardii., a tropical silicoflagellate, and $D$. stapedia, a low nutrient indicator (Fig. 7) dominate the silicoflagellate assemblage, $D$. franshepardii comprises between $\sim 10$ and $50 \%$, whereas D. stapedia mostly ranges between 5 and $30 \%$. O. pulchra never makes up more than $30 \%$ of the silicoflagellate assemblage. Increases in \% D. stapedia coincided with decreases in $\% D$. franshepardii, particularly between $\sim$ A.D. 1060 and 1220 and after $\sim$ A.D. 1770. Amplitude fluctuations are greatest for $D$. franshepardii ( $\sim 10$ to $55 \%$ ), whereas those of $D$. stapedia are $\sim 2$ to $30 \%$. The tropical silicoflagellate, D. calida, ranges between $\sim 4$ and $20 \%$, with the record after $\sim$ A.D. 1300 characterized by lower percentage values of $D$. calida $(<10 \%)$ and higher percentage values of $D$. franshepardii $(>25 \%)$. The Dictyocha "aculeata" group varies between $\sim 4$ and $30 \%$, with the strongest negative correlations are with $\%$ $O$. pulchra and the winter production diatom group.

The $\%$ biogenic opal data of Douglas et al. (in press) has been added for comparison with $\% O$. pulchra at the top of Fig. 7. The sediments are relatively low in $\%$ biogenic opal (mean $\sim 15 \%$ ) compared to those of NH01-21 (30-40\%, R. Douglas, written comm., 2005) and those of BAM80 E-17 (20 to 40\% biogenic silica) (Fig. 2). The \% biogenic opal record does not appear to correlate with the relative abundance records of any diatom or silicoflagellate taxa.

\section{Discussion}

\subsection{Seasonal vs. annual SST}

The diatom and silicoflagellate assemblages in the three cores represent a composite of multiple years of 

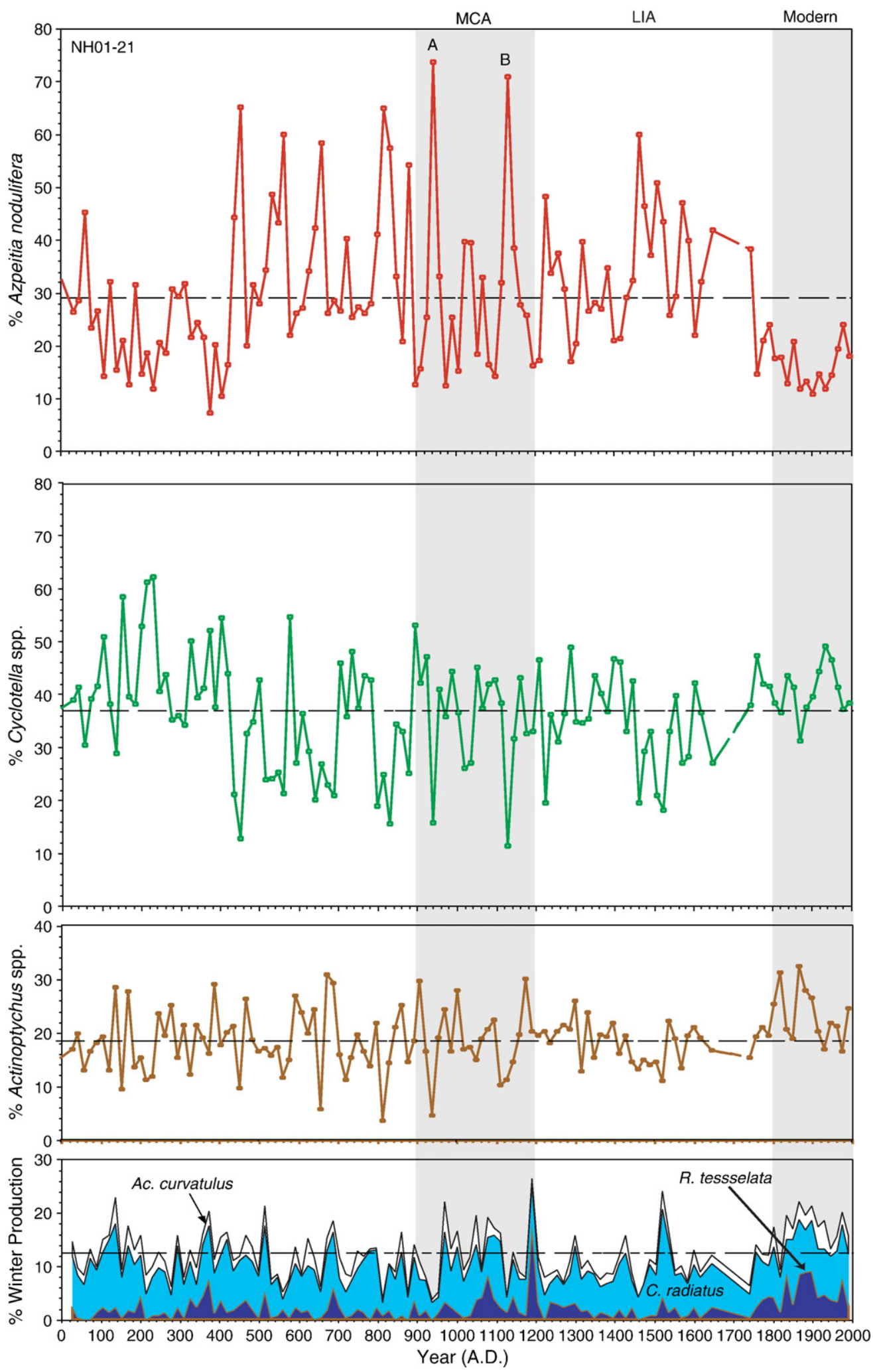

Fig. 4. Comparison of the percentages of the key diatom taxa during the past $2000 \mathrm{yr}$ in NH01-21. Percentages are of selected diatom taxa, see Materials and methods. Dashed line $=$ mean. 

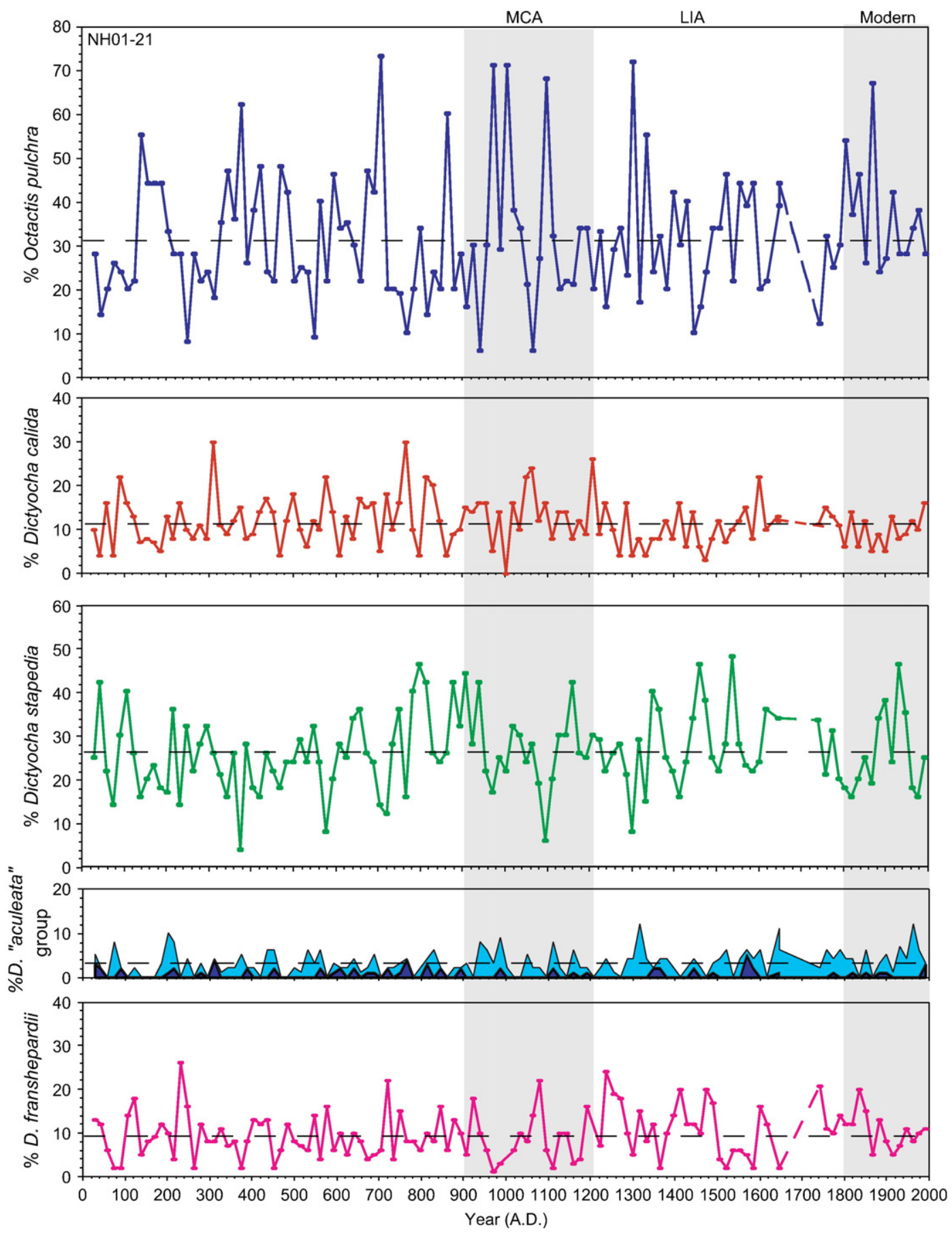

Fig. 5. Comparison of the relative contributions of key silicoflagellates during the past $2000 \mathrm{yr}$ in NH01-21. Dashed line $=$ mean.

varved sediment deposition. Based on the various sedimentation rates, the approximate 1-cm-thick samples represent between $\sim 7$ (BAM80 E-17) and 23 (NH0126) yr of deposition. Each annual varve contains the assemblages of both the winter (actually, the late fall to early spring) and summer (the late spring to early fall) phases of Gulf climate. Thus, the relative proportion of winter vs. summer diatom and silicoflagellate taxa in a given sample of the three cores is assumed to reflect the relative dominance (or strength) of winter vs. summer 

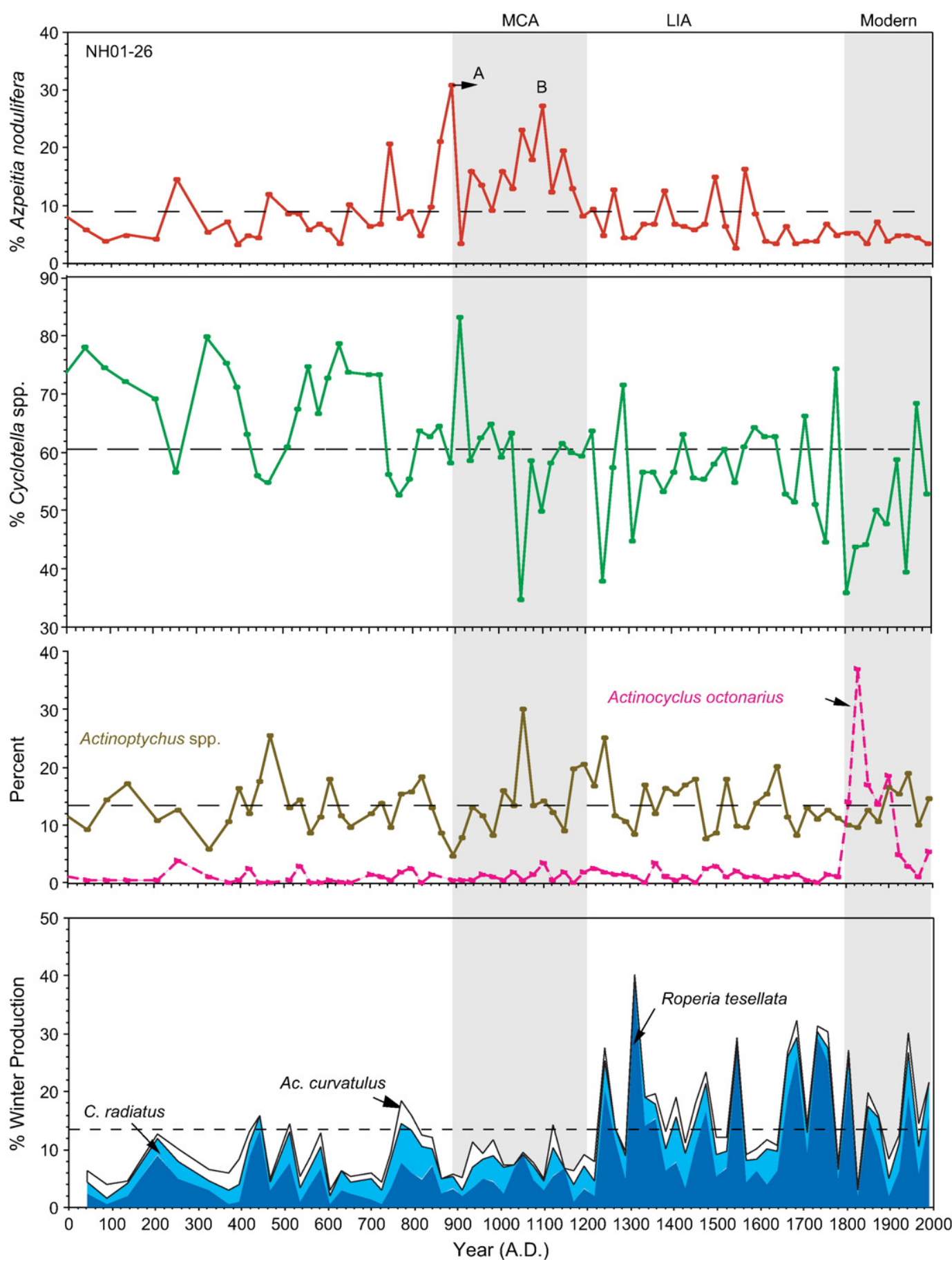

Fig. 6. Comparison of the percentages of the key diatom taxa during the past $2000 \mathrm{yr}$ in NH01-26. Percentages are of selected diatom taxa, see Materials and methods. Dashed line $=$ mean.

deposition over the $\sim 7$ to 23 yr period of sample deposition. This assumption seems reasonable based on the sediment trap studies of Thunell (1998) and the varve studies of Kemp et al. (2000). Increased dominance of $O$. pulchra (the productivity proxy silicoflagellate) and/or the winter production diatoms (A. curvatulus, C. radiatus, and $R$. tesselata) relative to the proxies for warmer SSTs (e.g., A. nodulifera, D. calida) and/or those for reduced 


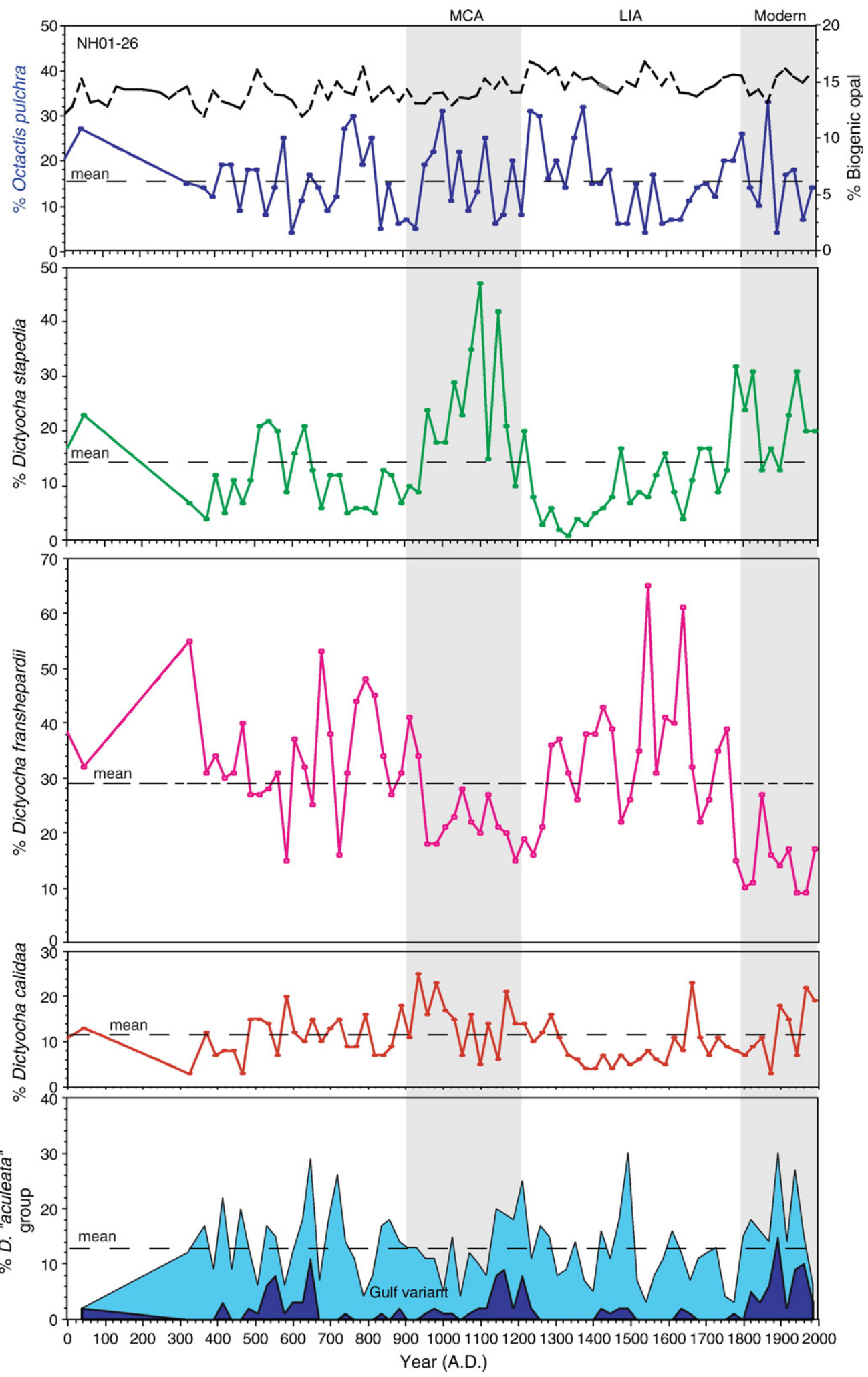

Fig. 7. Comparison of the relative contributions of key silicoflagellates during the past $2000 \mathrm{yr}$ in NH01-26. Gulf variant refers to Dictyocha sp. aff. D. aculeata. Percent biogenic opal (closely-spaced dashed line) after R. Douglas (written, comm., 2005). 
productivity (D. stapedia) in an individual sample is assumed to reflect the dominance of the winter phase of Gulf climate over the summer phase during the period of deposition of the sample.

\subsection{The medieval climate anomaly}

Both diatoms (Fig. 2) and silicoflagellates (Fig. 3) display distinctive assemblage changes during the early parts ( A.D. 900 to 1200) of the Medieval Climate Anomaly (MCA) in BAM80 E-17. Two prominent relative abundance peaks of the tropical diatom, $A$. nodulifera, one between A.D. 900 and 1020 (peak "A") and another between at A.D. 1100 and 1160 (peak "B") mark the MCA at BAM80 E-17. These peaks are interrupted by a low (trough "z"; $<10 \%$ ) centered on A.D. 1050 (Fig. 2). Intervals of reduced values of $O$. pulchra, as well as reduced $\%$ biogenic silica coincide precisely with the peaks of \% A. nodulifera in BAM80 E-17 (Fig. 3), suggesting that higher SST and a reduced late fall to early spring season of biosiliceous productivity typified these intervals. Conversely, coincident with the low in $\% A$. nodulifera ( A.D. 1050) (Fig. 3), there are sharp increases in both \% O. pulchra and \% biogenic silica (Fig. 3). Two prominent peaks in the $\%$ D. "aculeata" group (Fig. 3) coincide with the two ( A.D. 900 to 1020 and $\sim$ A.D. 1100 to 1160) intervals of increased $\% A$. nodulifera and decreased $\%$ O. pulchra and $\%$ biogenic silica. The $\% D$. aculeata plot data of the MCA resembles that of $\%$ A. nodulifera (Fig. 2) (correlation coefficient of 0.412 between these two taxa).

Similar to the diatom record at BAM80 E-17, the MCA of NH01-26 is marked by anomalous increases in the values of $A$. nodulifera (Fig. 6). A sharp, $\sim 30 \%$ peak in A. nodulifera at $\sim$ A.D. 880 (peak "A") and a broader peak of $>20 \%$ in $A$. nodulifera between $\sim$ A.D. 1050 and 1100 (peak "B") in NH01-26, may be equivalent to peaks "A" and "B" of BAM80 E-17 ( A.D. 940 and 1020) given the limited accuracy of the NH01-21 age model. These increases in $\%$ A. nodulifera along with a general decrease in the percentage values of the winter diatom group, imply that higher SST and reduced diatom productivity may have typified the MCA at NH01-26.

Silicoflagellates also record a distinctive MCA at NH01-26. A broad relative abundance peak of D. stapedia occurs between $\sim$ A.D. 960 and 1200 during an interval of slightly reduced \% biogenic silica and moderately reduced \% D. franshepardii (Fig. 7). The tropical silicoflagellate $D$. calida is about 5 to $10 \%$ more abundant during this interval at NH01-26 than it is during the following interval of the Little Ice Age (LIA). The onset and termination of this silicoflagellate MCA in NH01-26 are roughly 60 to $80 \mathrm{yr}$ younger than the limits of the MCA suggested by diatoms. Both proxies argue for increased influx of tropical Pacific waters into the mouth of the Gulf during the MCA, but their offset suggests that they are recording different surface water conditions. Detailed study using other proxies for SST (e.g., isotopes, alkenones) might resolve this discrepancy.

The interval identified as the MCA in NH01-21 (between $\sim$ A.D. 900 and 1200; Fig. 4) does not possess the unique relative abundance peaks in $\%$ A. nodulifera found in BAM80 E-17 (Fig. 2) and NH01-26 (Fig. 6). Peaks "A" and "B" of \% A. nodulifera (at A.D. 940 and 1130, respectively in NH01-21; Fig. 4) may correlate with peaks "A" and "B" of BAM80 E-17 ( A.D. 920 to 980 and $\sim$ A.D. 1120; Fig. 2), but similar \% A. nodulifera peaks occur in the NH01-21 record between $\sim$ A.D. 450 and 860. Indeed, neither diatoms (Fig. 4) nor silicoflagellates (Fig. 5) in NH0121 display any distinctive assemblage changes during the MCA. Core NH01-21 lies closer to the mainland coast than either BAM80 E-17 or NH01-26, and its record may be more sensitive to the incursions of tropical waters, which move northward along the mainland coast during the summer (Marinone, 2003).

\subsection{The Little Ice Age}

The LIA, which is recognized by many researchers as the interval between A.D. 1300 and 1850 (http:// en.wikipedia.org/wiki/Little_Ice_Age) is not as distinctive as the MCA in BAM80 E-17 in terms of its diatom and silicoflagellate assemblages. Lowered values of $A$. nodulifera mark the LIA, with the exception of a peak ("C") estimated to be between $\sim$ A.D. 1520 and 1560 . A stepwise increase in the $\%$ D. stapedia record at $\sim$ A.D. 1300 is most distinctive silicoflagellate assemblage change during the LIA in BAM80 E-17 (Fig. 3), implying reduced productivity. A prominent relative abundance peak in $\%$ D. stapedia of $\sim 30-40 \%$ between $\sim$ A.D. 1480 and 1520 coincided with a marked reduction (to values $<55 \%$ ) in \% O. pulchra (Fig. 3).

Similar to the BAM80 E-17 records (Figs. 2,3), the LIA in NH01-21 does not contain distinctive diatom and silicoflagellate assemblages (Figs. 4,5). There is a reduction in the amplitude of $\% A$. nodulifera with peak values typically $<40 \%$ between $\sim$ A.D. 1200 and 1800 in NH01-21, suggesting a reduction in the influx of tropical waters during the LIA. A peak ( $>55 \%)$ in A. nodulifera values estimated at $\sim$ A.D. 1460 in NH01-21 (peak "C, Fig. 4), possibly correlates with $\%$ A. nodulifera peak "C" ( $\sim$ A.D. 1520 to 1560 ) in the more tightly age-constrained record of BAM80 E-17 (Fig. 2). Amplitude variations of 
\% Cyclotella spp. and \% Actinoptychus spp. are also somewhat reduced during the LIA in NH01-21 (Fig. 4) compared to those of the preceding $\sim 750 \mathrm{yr}$, and there is a strong negative correlation (correlation coefficient -0.821 ) between \% Cyclotella spp. and \% A. nodulifera.

The LIA of NH01-26 is characterized by much reduced $(<10 \%)$ values of $\% A$. nodulifera (Fig. 6) similar to the $\%$ A. nodulifera records of BAM80 E-17 and NH01-21 (Figs. 2,4). Minor relative abundance peaks "C1" ( A.D. 1500) and "C2" ( A.D. 1570) of \% A. nodulifera (Fig. 6) may correlate with peak "C" ( A.D. 1520 to 1560 ) in the BAM80 E-17 record (Fig. 2). Prior to $\sim$ A.D. 1250, the winter diatom production group typically made up 5 to $16 \%$ of the tabulated diatom assemblage of NH01-26. During the LIA, however, relative abundance peaks $(>24 \%)$ of the winter diatom production group occurred regularly, roughly every $80 \mathrm{yr}$. These LIA peaks in winter diatom production are mostly driven by $\%$ increases in the relative abundance of $R$. tesselata, a diatom that is most common today in the waters of the northern Gulf (Schrader et al., 1986).

The LIA of NH01-26 is characterized by decreased $(<14 \%)$ values of $D$. stapedia, the low productivity silicoflagellate, and by increased (>30\%) values of $D$. franshepardii (Fig. 6). There is a minor increase in \% biogenic silica during the LIA at NH01-26, but increases of $\%$ O. pulchra are confined to the early part of the LIA (Fig. 6). It's possible that dissolution has selectively removed the more delicate skeletons of $O$. pulchra from the NH01-26 silicoflagellate assemblages.

\subsection{The last $\sim 100$ to $200 \mathrm{yr}$ (modern)}

The diatom record of the last $\sim 100$ to $200 \mathrm{yr}$ in BAM80 E-17 is not distinctive, aside from a prominent relative abundance increase in \% Actinoptychus spp at $\sim$ A.D. 1850 (Fig. 2). Silicoflagellates $(O$. pulchra) and biogenic silica (Fig. 3) both record sharp drops in productivity in the uppermost part of the core (Fig. 5, Barron et al., 2003). Associated with these sharp declines in productivity, there is a marked increase (>15\%) in the \% D. "aculeata" group (Fig. 3), similar to increases during the MCA. Schrader and Baumgartner (1983) documented an increase in \% $D$. aculeata (recorded by them as D. epiodon) in recent sediments throughout the central Gulf, with peak values ( $>5 \%$ of their counts) estimated to be at $\sim$ A.D. 1910. According to this chronology, the $20 \mathrm{~cm}$ interval of BAM80 E-17 would be equivalent to $\sim$ A.D $>1910$, rather than $\sim$ A.D. 1830 (Table 2), suggesting that the drop in \% biogenic silica at that site (Barron et al., 2003) occurred between $\sim$ A.D. 1870 and 1910.
Recent warming of surface waters of BAM80 E-17 agrees in most part with the alkenone SST studies of Goñi et al. (2001), who documented a steady $2{ }^{\circ} \mathrm{C}$ warming of the surface waters of the central Gulf between the early 1700 s and the 1950 s, followed by a rapid apparent $1{ }^{\circ} \mathrm{C}$ cooling between the 1950 s and 1980s.

In contrast to the BAM80 E-17 record, both diatoms and silicoflagellates argue for increased biosiliceous productivity in the uppermost part of NH01-21, the coastal upwelling core from the south central Gulf (Figs. 4,5). The values of $O$. pulchra increased to $>45 \%$ between $\sim$ A.D. 1800 and 1900, before falling to average values near 35\% after $\sim 1900$ (Fig. 5). The winter diatom production group increased by 5 to $10 \%$ during the same $\sim 1800$ to 1900 interval (Fig. 4). Associated with this productivity increase, there is a drop in the amplitude and values of $A$. nodulifera (Fig. 4), implying a decrease in SST in the immediate area. This recent productivity increase in NH01-21 might reflect increased nutrient input to local waters due to agriculture in the adjacent Yaqui Valley. Although agriculture intensified in the Yaqui Valley at $\sim$ A.D. 1950 (Bema et al., 2005), the fertile farms of the valley were farmed for at least $200 \mathrm{yr}$ before that time (http:// www.houstonculture.org/mexico/sinaloa.html). Improved dating and application of geochemical proxies are needed to test this hypothesis.

The onset of the modern period in NH01-26 (dated at $\sim$ A.D. 1800 in Fig. 6, but possibly $\sim$ A.D. 1850; Staines-Urias and Douglas, in press) is marked by a sharp decline in \% Cyclotella spp. that coincides with a sharp increase in \% Actinocyclus octonarius, a cosmopolitan planktonic diatom that is common in coastal and brackish waters. The significance of this relative abundance peak $(\sim 15 \%)$ of $\%$ A. octonarius is unclear, as it is not seen in either NH01-21 or BAM80 E-17.

The silicoflagellate assemblages of the uppermost part of NH01-26 resemble those of the MCA in that core, as they are typified by an increased $\%$ D. stapedia and a decreased $\%$ D. franshepardii (Fig. 7). The $\%$ biogenic silica during this period is generally unchanged from that of the proceeding LIA. High resolution oxygen isotope studies of the planktonic foraminifer $G$. bulloides at NH01-26 suggest $\mathrm{a} \sim 2{ }^{\circ} \mathrm{C}$ warming of winter surface waters since $\sim$ A.D. 1850 (Staines-Urias and Douglas, in press).

\subsection{Solar influence on Gulf SST}

Diatoms and silicoflagellates suggest a complex evolution of Gulf surface waters during the past $2000 \mathrm{yr}$ 
(Figs. 2-7). The MCA ( A.D. 900-1200) of BAM80 E-17 and NH01-26 appears to have been distinctly warmer than earlier and later periods, with reduced biosilica production. On the other hand, the strong cyclic character of the NH01-21 MCA record likely reflects its location within a region dominated by coastal upwelling.

Goñi et al. (in press) demonstrated a strong negative correlation of alkenone SST records in the Guaymas Basin and solar insolation. They argued that during periods of enhanced solar insolation (greater sunspot numbers), the northward migration of the North Pacific Subtropical High would have enhanced the efficiency of northwest winds and increased upwelling in the
Guaymas Basin. The following section discusses the possibility of a solar influence on the diatom and silicoflagellate assemblages in the Gulf during the past $2000 \mathrm{yr}$.

\subsection{Solar influence on Gulf diatom and silicoflagellate records}

Fig. 8 reproduces Barron et al.'s (2003) correlation of the $\%$ biogenic silica record of BAM80 E-17 with the radiocarbon production curve of Stuiver et al. (1998) and includes the sunspot record of the past $400 \mathrm{yr}$ (http:// www.ngdc.noaa.gov/stp/SOLAR/ftpsunspotnumber. html). Shaded intervals imply a correlation between

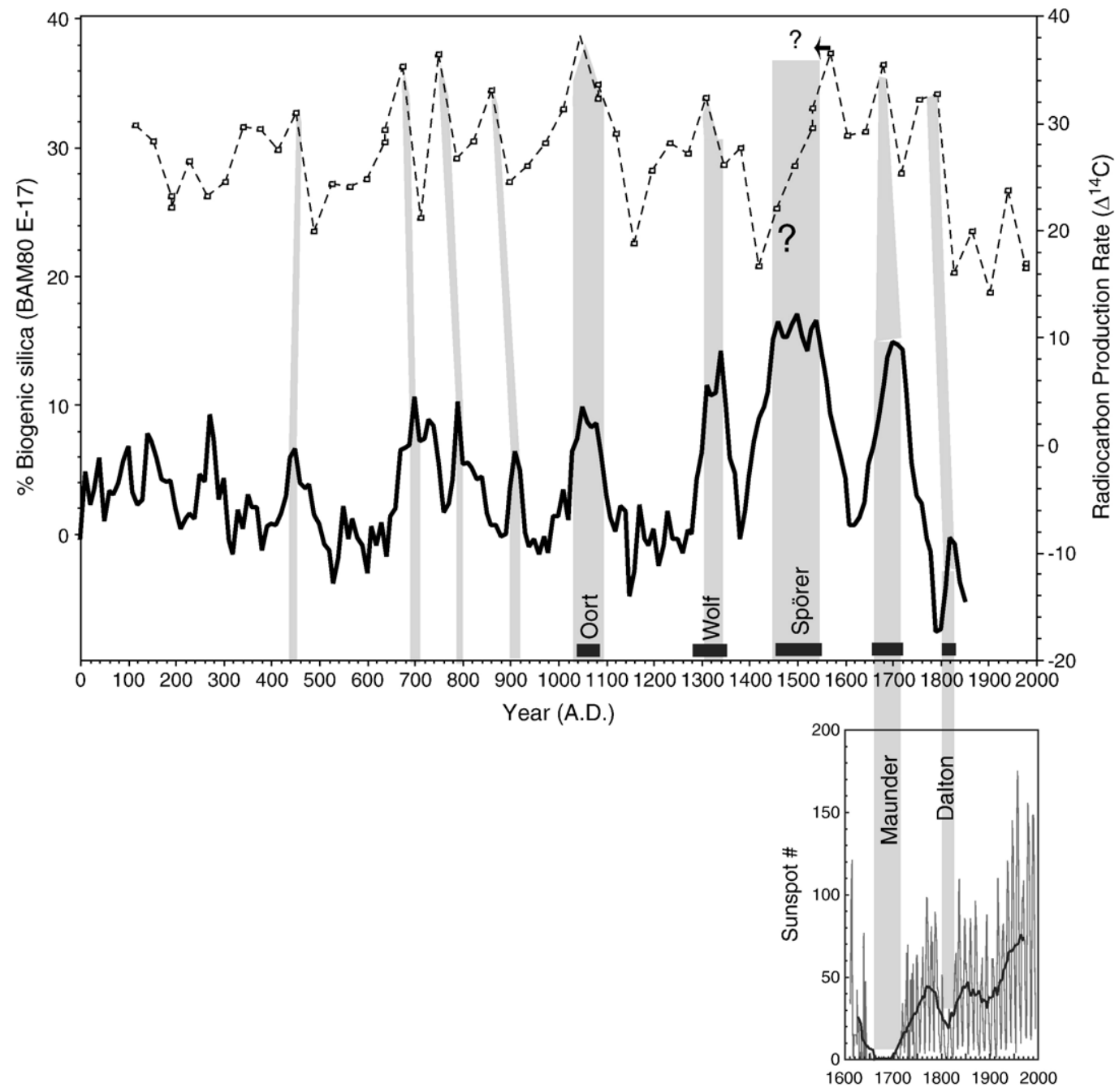

Fig. 8. Correlation of the \% biogenic silica record of BAM80 E-17 (dashed line) (Barron et al., 2003) with the radiocarbon production curve of Stuiver et al. (1998) and the sunspot record of the past $400 \mathrm{yr}$ (downloaded at http://www.ngdc.noaa.gov/stp/SOLAR/ftpsunspotnumber.html, based on data from the Solar Influences Data Analysis Center (SIDC) in Belgium). 


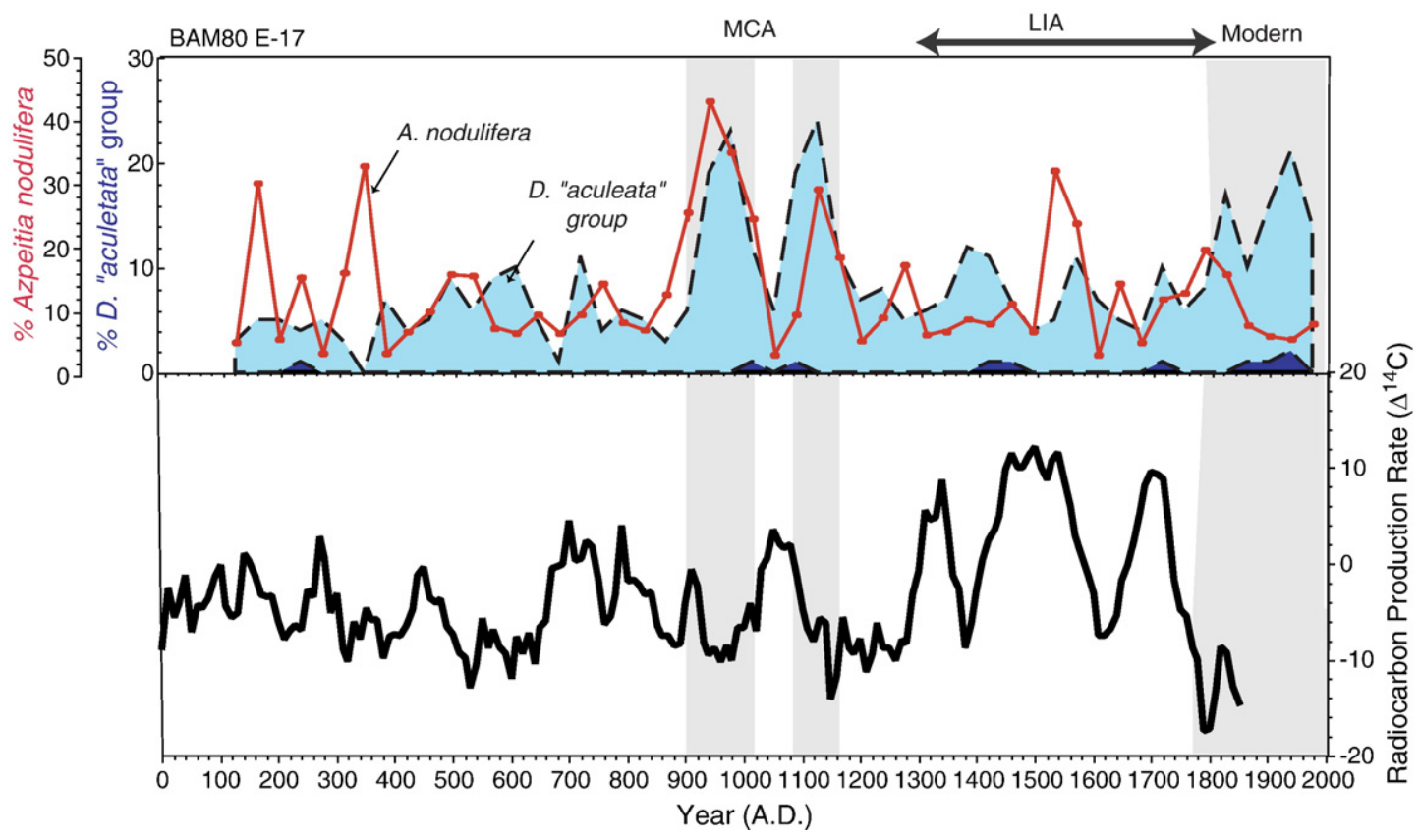

Fig. 9. Correlation of the tropical SST proxies \% Azpeitia nodulifera and \% Dictyocha "aculeata" group in BAM80 E-17 with the radiocarbon production curve of Stuiver et al. (1998).

increased radiocarbon production, which occurs during reduced solar irradiance and reduced sunspot number, and increased biosilica production in the eastern
Guaymas Basin. This correlation is limited by the sample resolution ( $\sim 40 \mathrm{yr})$ of the $\%$ biogenic silica data, yet almost all of peaks of $\%$ biogenic silica

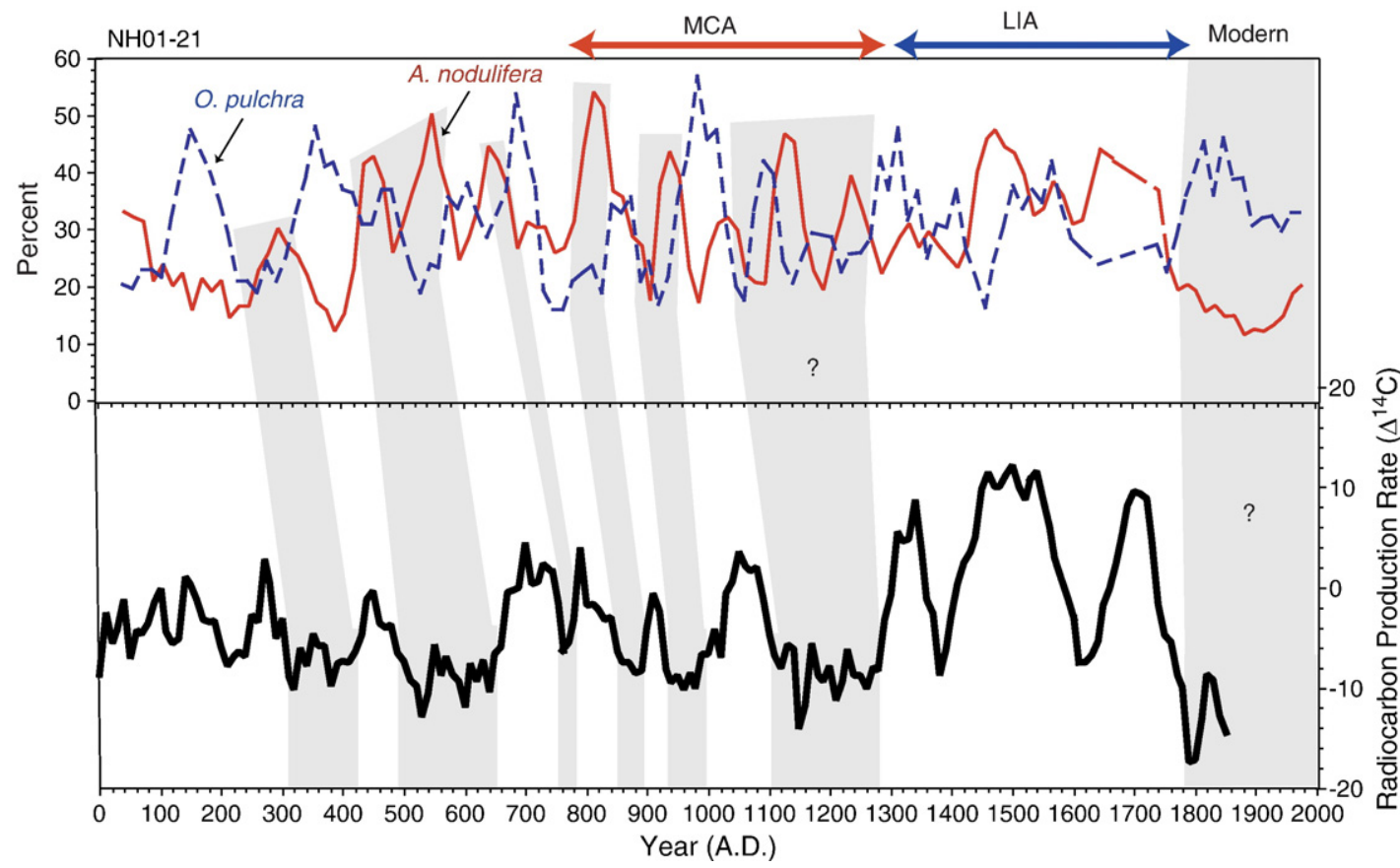

Fig. 10. Correlation of smoothed (3pt-running mean) \% Azpeitia nodulifera (tropical SST proxy) and \% Octactis pulchra (high productivity proxy) data in NH01-21 with the radiocarbon production curve of Stuiver et al. (1998). 
correlate with production peaks of radiocarbon. The apparent correlation, however, breaks between $\sim$ A.D. 1450 to 1550 , where reduced and/or increasing \% biogenic silica correlates with the interval of the Spörer sunspot minimum.

Barron et al. (2003) argued that reduced solar irradiance associated with sunspot minima (Shindell et al., 2001) would cause atmospheric cooling above the southwest US during the winter. This would lead to increased in the strength and/or duration of late fall/ winter northwest winds blowing down the Gulf, enhanced over turn of surface waters, cooler SST, and increased the production of biogenic silica.

As shown by Fig. 9, prominent MCA peaks of $\%$ A. nodulifera and $\%$ D. "aculeata" group in BAM 80 E-17 coincide with lows in the radiocarbon production curve. This suggests that surface water warming during these parts of the MCA in the northern part of the central Gulf may have been driven by increased solar irradiance.

Recent reconstruction of PDO for the last millennia by MacDonald and Case (2005), implies that the MCA between $\sim$ A.D. 1000 and 1300 was characterized by negative values of PDO. Our suggestion of warmer SSTs in the central Gulf during this period of negative PDO is at odds with studies such as Baumgartner and Christensen (1985), Lavîn et al. (2002) which relate recent positive anomalies of SST in the Gulf with strong El Niño events. It should be remembered, however, that our diatom and silicoflagellate records reflect the relative dominance of the winter (high productivity, dominant northwest winds, cool SST) vs. summer (low productivity, reduced winds, warm SST) in individual samples representing between $\sim 7$ and $23 \mathrm{yr}$ of deposition. Detection of 3 to $7 \mathrm{yr}$-long ENSO cycles is beyond the resolution of our data.

Increasing solar irradiance (sunspot numbers) during the past $\sim 100 \mathrm{yr}$ might also be responsible for an increase in SST that is implied by an increase in the \% D. "aculeata" group, the alkenone studies of Goñi et al. (in press), and reduced \% biogenic silica in BAM80 E-17 (Fig. 8).

High amplitude cycles of $\sim 100 \mathrm{yr}$ duration of both A. nodulifera and $O$. pulchra characterize the NH01-21 record (Figs. 4,5). On Fig. 10, \% A. nodulifera and \% O. pulchra are smoothed over a three point running mean and compared with the radiocarbon production curve. Peaks in the smoothed $\%$ A. nodulifera coincide closely with troughs in the smoothed \% O. pulchra data, suggesting periods marked by increased incursions of tropical waters and reduced productivity. Correlation of these warmer intervals with intervals of reduced radiocarbon production is proposed between $\sim$ A.D. 300 and 1300. Intervening peaks in the smoothed \% O. pulchra data seem to match peaks of increased radiocarbon production and reduced solar irradiance. After $\sim$ A.D. 1300, however, this correlation is more problematic.

Fig. 11 compares the wavelet power spectra (Torrance and Campo, 1998) of O. pulchra and A. nodulifera in NH01-21. The resolution of the power spectra is limited by the 16 yr-sample spacing. $O$. pulchra abundance data show a strong power in the $\sim 256 \mathrm{yr}$ range, particularly between $\sim$ A.D. 0 and 700. During the MCA (between $\sim$ A.D. 850 and 1200), there is increased power in the $\sim 128$ to $112 \mathrm{yr}$ period. The $\% A$. nodulifera record displays the strongest power in the $\sim 100$ yr period between $\sim$ A.D. 400 and 600 and between $\sim$ A.D. 800 and 1300, intervals coinciding with reduced radiocarbon production (increased solar irradiance). Damon and Sonnett (1991) identify cycles in radiocarbon production of 105 and $131 \mathrm{yr}$ which they relate to solar variability. The Gleissburg solar cycle is typically thought to be between 80 and $90 \mathrm{yr}$ in length, but Le and Wang (2003) argue that it has a dominant $101 \mathrm{yr}$ period based on their wavelet analysis of the sunspot number series between A.D. 1700 and 2002.

Fig. 12 proposes a correlation of the $\%$ A. nodulifera and $\%$ D. stapedia data in NH01-26 with the
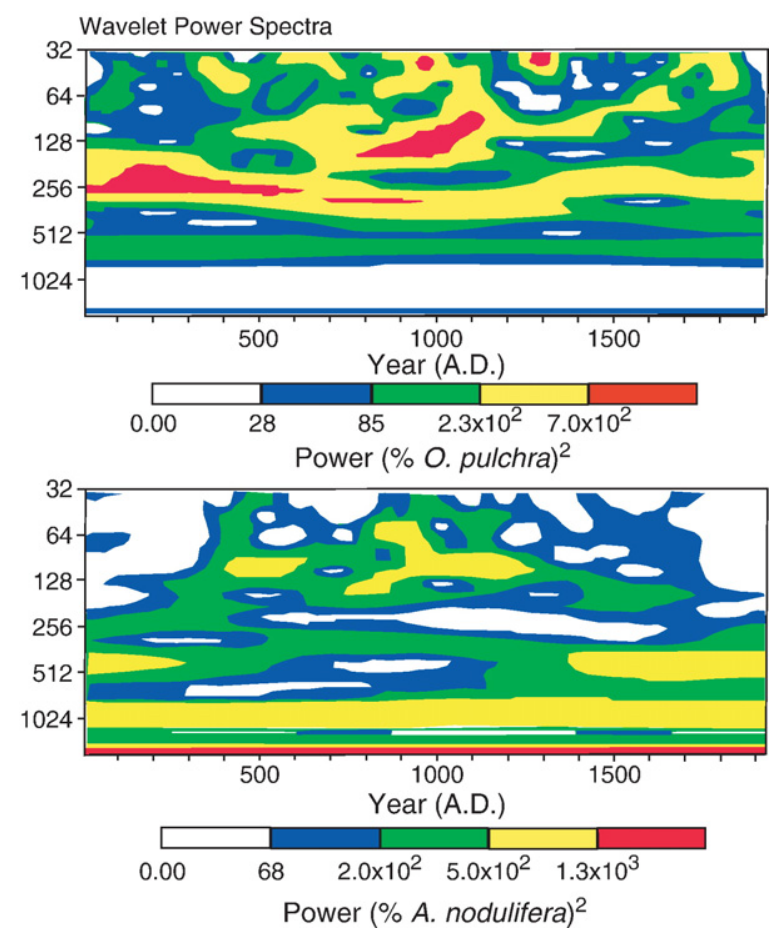

Fig. 11. Wavelet power spectra of \% Azpeitia nodulifera and \% Octactis pulchra data in NH01-21. 


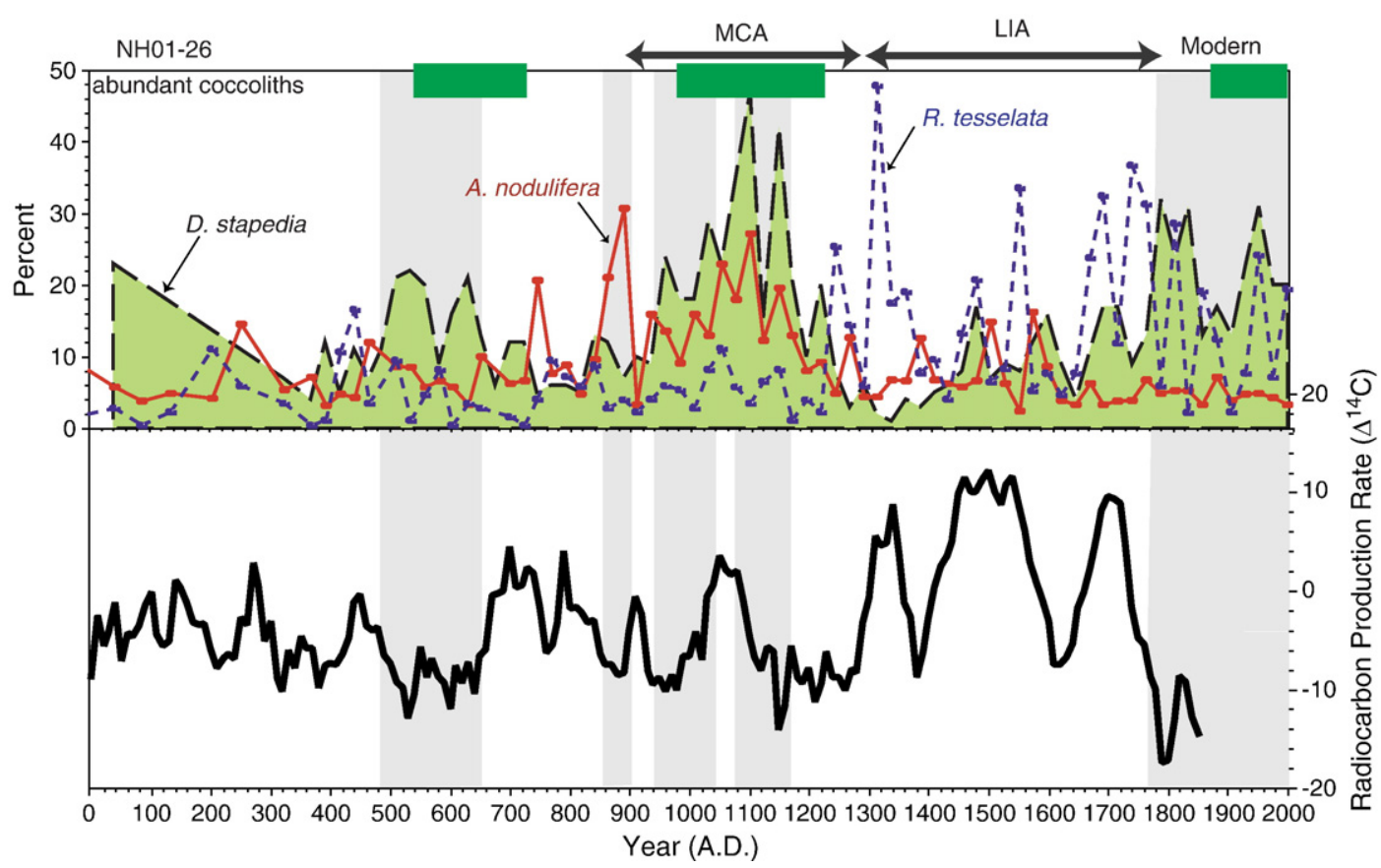

Fig. 12. Correlation of \% Azpeitia nodulifera (tropical SST proxy), \% Roperia tesselata (winter production diatom) and \% Dictyocha stapedia (proxy for oligotrophic waters) data in NH01-26 with the radiocarbon production curve of Stuiver et al. (1998). Intervals of abundant coccolith occurrence in NH01-26 also shown.

radiocarbon production curve. The location of $\mathrm{NH} 01-26$ at the mouth of the Gulf is strongly affected by waters of the tropical Pacific, so one would expect strong ENSO forcing of its diatom and silicoflagellate assemblages. However, the $\sim$ A.D. 1000 to 1300 period of predominantly negative PDO in the reconstructions of MacDonald and Case (2005) is characterized by diatoms and silicoflagellates that are more typical of warmer, less productive conditions in NH01-26. After A.D. 500 most of the intervals of increased $\%$ D. stapedia seem to correlate with intervals of decreased radiocarbon production, implying reduced productivity and warming of SST during intervals of increased solar irradiance. Prominent increases of $\%$ A. nodulifera between $\sim$ A.D. 850 and 1160 also match MCA intervals of reduced radiocarbon production. Three intervals of abundant coccolith occurrence (determined by reconnaissance examination of the slides) ( $\sim$ A.D. 550 to 720 ; A.D. 1000 to 1240 ; and $\sim$ A.D. 1860 to 2000 A.D) coincide with intervals of warmer surface waters suggested by $\%$ $A$. nodulifera and $\% D$. stapedia. The $\% R$. tesselata record of NH01-26 reveals that this winter production diatom is most common during the LIA, particularly during intervals of increased radiocarbon production (Fig. 12).

Diatom and silicoflagellate proxy records for productivity and SST suggest that solar forcing played a major role in determining surface water conditions in the Gulf of California during the past 2000 yr. During periods of reduced solar irradiance (sunspot minima), increased winter cooling of the atmosphere above the southwest US may have caused strengthening of the atmospheric low, leading to intensification of northwest winds blowing down the Gulf, increasing overturn of surface waters, and enhancing biosiliceous productivity in the Gulf. During the summer, variations in solar irradiance probably affected the northward migration of the ITCZ (Wang and Wang, 1999; Poore et al., 2004), which influences the intensity of northward flow of tropical surface waters into the Gulf. Clearly, improved age models for cores NH0121 and NH01-26, higher resolution studies, and application of other proxies for SST such as alkenones, $\mathrm{Mg} / \mathrm{Ca}$, and oxygen isotopes in these and other cores are needed in order to evaluate this hypothesis.

\section{Conclusions}

- High-resolution $(<100 \mathrm{yr})$ records of diatoms and silicoflagellate assemblages of the past $2000 \mathrm{yr}$ are compared in a north-south transect $\left(28^{\circ} \mathrm{N}\right.$ to $\left.24^{\circ} \mathrm{N}\right)$ of three cores from the eastern slopes of the Gulf of California.

- Diatoms and silicoflagellate records capture the seasonal variation between a late fall to early spring 


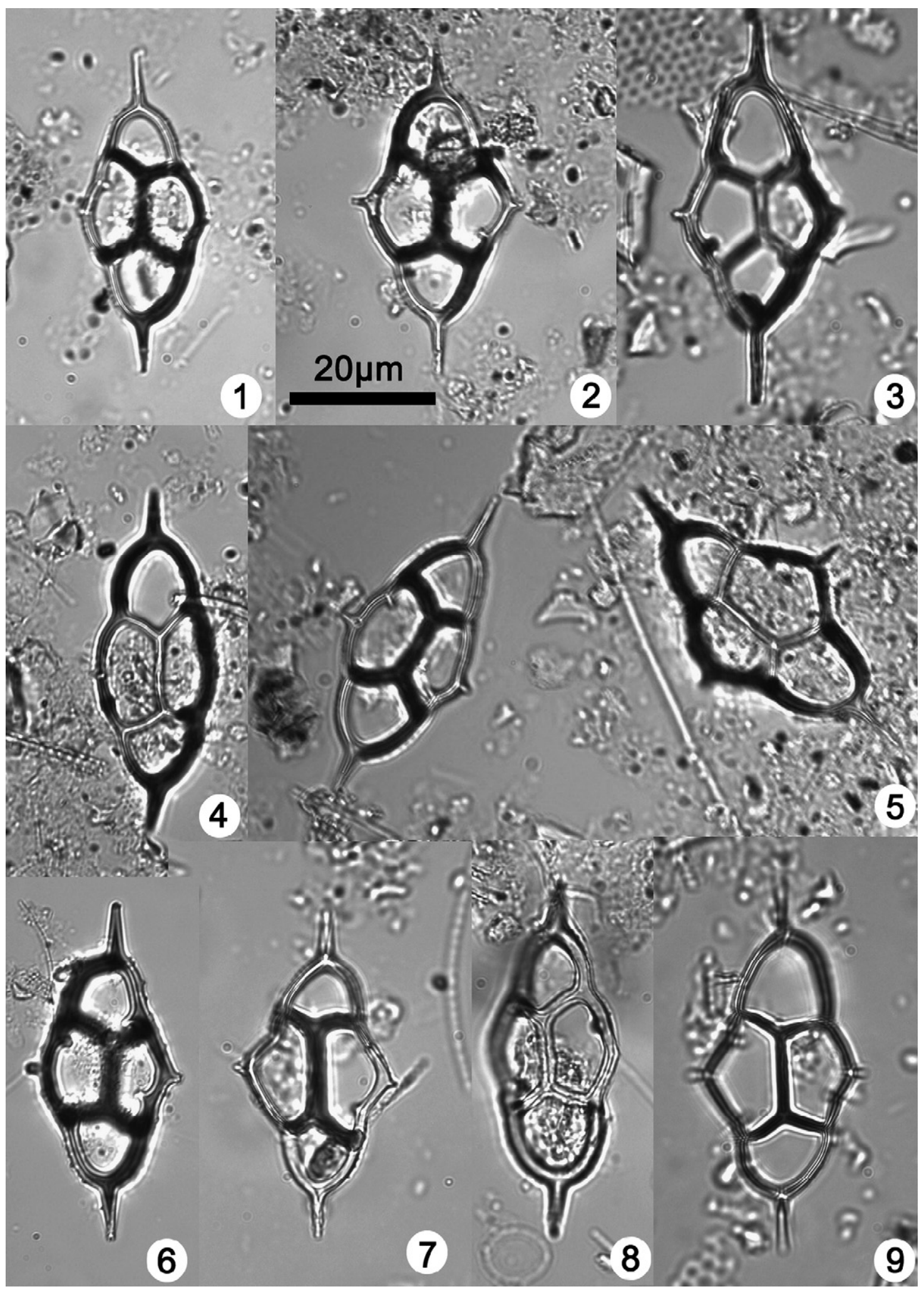


period of high biosiliceous productivity that is driven by northwest winds, and a summer period of warmer, less productive waters during which these winds slacken and/or reverse direction (monsoonal flow).

- Intervals of enhanced summer incursion of tropical waters, with alternating periods of increased late fall to early spring biosiliceous productivity, characterize the records of all three cores.

- Core NH01-21 $\left(26.3^{\circ} \mathrm{N}\right)$ beneath a coastal upwelling cell in the Carmen Basin, contains regularly-spaced cycles ( $100 \mathrm{yr}$ duration) of $O$. pulchra, a silicoflagellate proxy for high productivity, and $A$. nodulifera, a tropical diatom, between $\sim$ A.D. 400 and $\sim$ 1700. Solar forcing of the upwelling cycles is proposed through the following teleconnection: reduced solar irradiance (sunspot minima) causes cooling of winter atmospheric temperatures above the southwest US. This strengthens the atmospheric low and leads to intensification of northwest winds blowing down the Gulf, resulting in increased overturn of surface waters, increased productivity, and cooler SST.

- The early part of the Medieval Climate Anomaly ( A.D. 900 to 1200$)$ in cores BAM80 E-17 (27.9 $\mathrm{N})$ and $\mathrm{NH} 01-26\left(24.3^{\circ} \mathrm{N}\right)$ is characterized by two periods of reduced productivity (warmer SST) with an intervening high productivity (cool) interval centered at $\sim$ A.D. 1050. Solar variability appears to have driven these productivity cycles, as intervals of increased radiocarbon production (sunspot minima) correlate with intervals of enhanced biosilica productivity, especially in BAM80 E-17. Confirmation of this hypothesis, however, requires, improved chronologies, higher resolution sampling, and the application of other proxies for productivity and SST.

- The last 100-200 yr in BAM80 E-17 and NH0126 resembles the MCA in those cores, as it is typified by diatoms and silicoflagellates that suggest reduced productivity and relatively warm SST.

- The last $\sim 100-200 \mathrm{yr}$ in NH0-21, on the other hand, contains diatoms and silicoflagellates suggestive of increased productivity, possibly reflecting the more nearshore location of the core and/or the input of nutrients from agriculture in the nearby Yaqui Valley.

- A new silicoflagellate species, D. franshepardii Bukry, is described and illustrated.

\section{Acknowledgements}

This manuscript benefited from reviews by Scott W. Starratt and David Wahl of the USGS. We are grateful to Robert Douglas, Francisca Staines-Urias, and Miguel Goñi for very helpful discussions and for providing us copies of their manuscripts. Thanks is also due to Robert Douglas for providing samples of NH01-21 and NH01-26. David Bukry acknowledges many helpful discussions on coastal geology and climate during 1977-1984 with Dr. Francis P. Shepard and his associate Gerald G. Kuhn at the Scripps Institution of Oceanography. We are grateful to suggestions offered by two anonymous reviewers and to the careful editing and numerous suggestions made by Ellen Thomas, the journal editor.

\section{Appendix A. Taxonomy}

\section{A.1. Diatoms}

The diatom taxa tabulated are the same ones tabulated by Barron et al. (2003, 2004, 2005)

Actinocyclus curvatulus Janisch, 1878

A. octonarius Ehrenberg, 1838

Actinoptychus bipunctatus Lohman, 1941

A. senarius (Ehrenberg) Ehrenberg, 1843

Azpeitia nodulifera (A. Schmidt) G. Fryxell and P.A. Sims, 1986

Coscinodiscus asteromphalus Ehrenberg, 1844

C. grannii Gough, 1905

C. radiatus Ehrenberg, 1839

C. oculusiridis Ehrenberg, 1841

Cyclotella littoralis Lange and Syvertsen, 1989

Roperia tesselata (Roper) Grunow ex Pelletan, 1889

Stephanopyxis palmeriana (Greville) Grunow, 1884

\section{A.2. New species of silicoflagellate}

Genus Dictyocha Ehrenberg, 1837

D. franshepardii Bukry, n. sp.

(Plate I, Figs. 1-9; Plate II, Figs. 1-5)

Dictyocha sp.2, Murray and Schrader, 1983, p.521, pl. II, figs. 11-13.

Dictyocha minima Schrader et al. (1986), p.208 (nomen nudum).

Plate I. Dictyocha franshepardii Bukry, n. sp. (1 to 6). Sample NH01-26, 15-17 cm. (1) isotype CAS slide number 22,026: (2) holotype CAS slide number 22,027; (3) isotype CAS slide number 22,027; (4) isotype CAS slide number 22,027; (5) two specimens in same field of view, isotypes CAS slide number 22,025; (6) isotype CAS slide number 22,026.(7 to 9). Sample NH01-21, 16-17 cm. (7) paratype CAS slide number 22,028, note very long bar; (8) paratype CAS slide number 22,028, no minor axis spines; (9) paratype CAS slide number 22,028. 


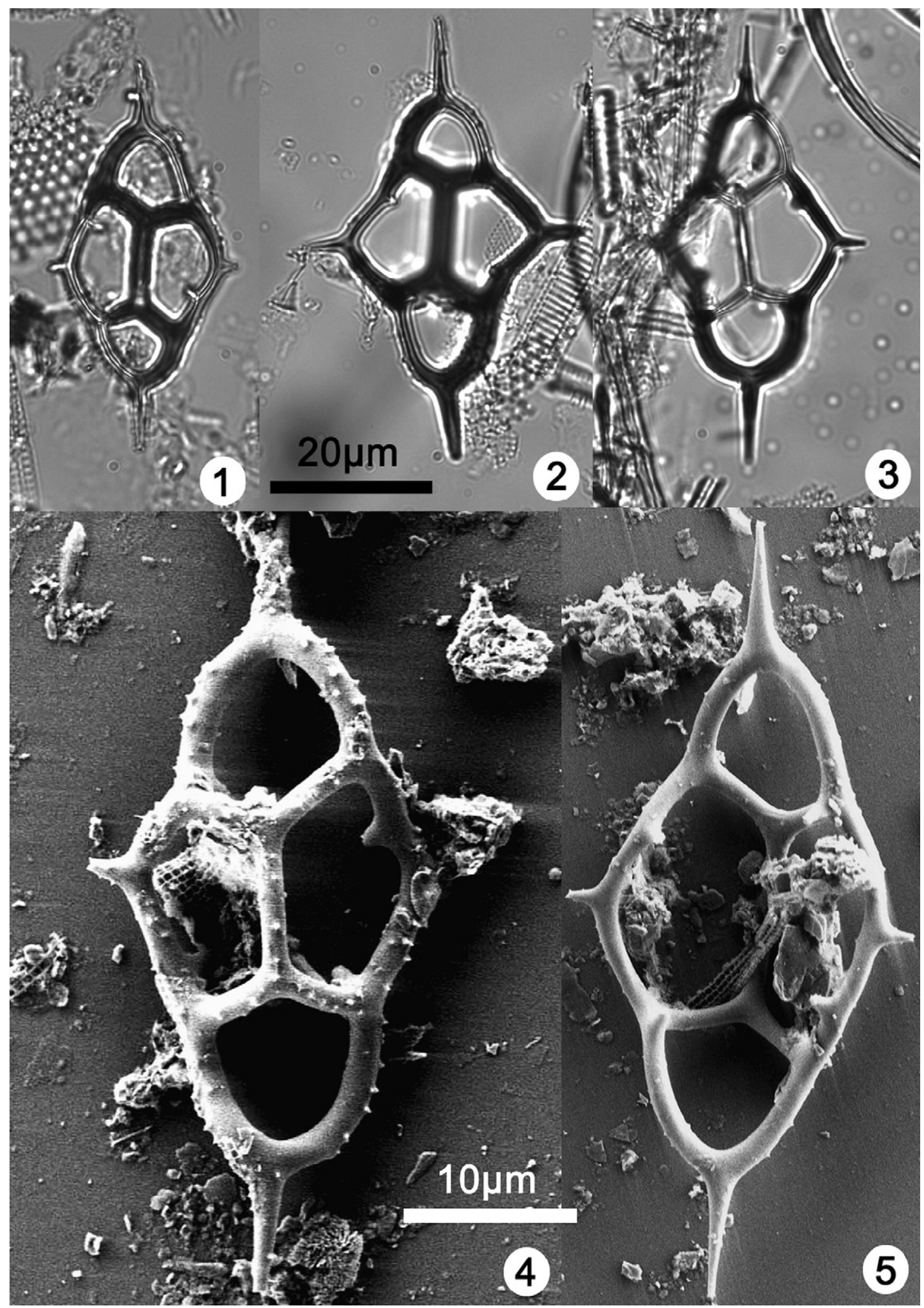




\section{A.2.1. Description}

D. franshepardii is moderate sized with a pronounced major axis elongation shown by inner-diameter length-towidth ratios of 1.6 to 2.4 (average 2.0). The elongation is supported by moderate major-axis spines and short minor axis spines. Major-axis spines may be slightly offset from the apical bar alignment. Slight asymmetries in proportions are shown by the inner-diameter lengths of the apical bar and two major-axis portals. Typically, there is one short portal at 25 to $29 \%$ (average $27 \%$ ) of the majoraxis inner diameter. The long portal at 28 to $38 \%$ (average $32 \%$ ) is still different from the even longer apical bar at 33 to $47 \%$ (average $41 \%$ ). A ratio between the portal lengths ranges from 1.07 to 1.38 (average 1.2). The major portal spined-ends are more rounded than the minor-axis portals which can be quite angular; also, the end curvatures of the major portals may not match each other. Two prominent pikes on the basal ring are widely offset from the strut junctions, whereas the other two are right at the strut junction. The strut patterns are slightly asymmetric, and, more notably, are curved or distinctly bowed out, apically, unlike most species which have straight struts. SEM detail shows nodular texture on apical surfaces and smooth texture on abapical surfaces (Plate II, Figs. 4, 5).

\section{A.2.2. Remarks}

D. franshepardii is distinguished from other species by one or more unique asymmetries. Especially distinctive are the elongate oval shape of the basal ring, unequal major portal lengths and spine and strut junction asymmetries. It is distinguished from $D$. longa, another elongate species $(L / W=1.3$ to 1.7 , mean 1.5$)$, by asymmetric strut pattern and unequal major axis portals. It is distinguished from coexisting elongate $D$. perlaevis by unequal portals, two prominent basal pikes and nonparallel-sided minor-axis portals and smaller size. Coexisting $D$. stapedia has a similar asymmetric strut and pike pattern, but has a rhombic unelongated basal ring. Murray and Schrader (1983, p.521) compared it to $D$. calida, but that species has straight struts, symmetric strut-ring junctions, nearly equal spines and regular symmetry, which help to distinguish it.

\section{A.2.3. Occurrence}

A census of 278 samples in three Gulf cores shows that $D$. franshepardii is sparse (1 to 5\%, mean $1.3 \%$ ) per sample in the central Gulf with little climatic affinity. It is more numerous ( 1 to $26 \%$, mean $9.1 \%$ ) and persistent in core NH01-21, where it also shows little climatic affinity. It is consistently the most abundant species of Dictyocha (8 to $64 \%$, mean $25.0 \%$ ) in southernmost Gulf core NH01-26, where it shows only slight affinities to warmer, more oligotrophic intervals as indicated by $O$. pulchra data. The numeric predominance of $D$. franshepardii in the southern Gulf suggests that its very small abundance in central Gulf core BAM80 E-17 prior to the beginning of the Medieval Climate Anomaly ( A.D. 941) may indicate cooler waters there.

Murray and Schrader (1983) also reported increasing relative abundances of $D$. franshepardii, southward in core top samples from six Gulf cores. But, in plankton samples it never had abundances greater than $2 \%$, so there was no apparent preferred distribution.

Schrader et al. (1986) showed D. franshepardii generally absent from a series of Gulf plankton samples taken in 1982 . The two maximum percent events, $12 \%$ and $8 \%$, were noted in the southern Gulf in equatorial surface waters at warm temperatures of 23.78 and $24.75{ }^{\circ} \mathrm{C}$, salinities of 34.7 and 34.3 and very low chlorophyll levels. However, no distinct distribution patterns were indicated (p.218). A warmer, lowproductivity relationship is supported by our core NH01-26 records which extend back to $7.3 \mathrm{kyr}$ (sample 303-304 cm), with 33\% D. franshepardii predominating.

\section{A.2.4. Name}

Named in honor of Dr. Francis P. Shepard, Scripps Institution of Oceanography, who was a marine geology pioneer for the Gulf of California. His students and associates, such as Joe Curray, Bob Dietz and Gene Rusnack, also advanced understanding of the sedimentation and structure of the Gulf.

\section{A.2.5. Size}

Maximum inner diameter 23 to $34 \mu \mathrm{m}$ (Holotype $27 \mu \mathrm{m}$; average $29 \mu \mathrm{m})$. Maximum length along major axis, 44 to $57 \mu \mathrm{m}$; average $48 \mu \mathrm{m}$.

\section{A.2.6. Holotype}

CAS slide number 22,027, sample NH01-26, 15$16 \mathrm{~cm}$ (Plate I, Fig. 2).

Plate II. Dictyocha franshepardii Bukry, n. sp. Scale bars equal $20 \mu \mathrm{m}$ for LM and $10 \mu \mathrm{m}$ for SEM. (1). Sample NH01-21, 16-17 cm; LM. Paratype CAS slide number 22,028.(2). Sample BAM 80 E-17, 25-26 cm; LM. Paratype CAS slide number 22,029, angular minor axis portals.(3). Sample BAM 80 E-17, 95-96 cm; LM. Paratype CAS slide number 22,030, one broadly rounded portal.(4, 5). Sample NH01-26, 57-58 cm; SEM. (4) Paratype, CAS accession number 625084, nodular texture on all apical surfaces; (5) Paratype CAS accession number 625084, smooth texture on all abapical surfaces; two basal pikes directly under the strut-ring junctions. 


\section{A.2.7. Isotypes}

CAS slide numbers 22,025, 22,026, and 22,027, sample NH01-26, 15-16 cm (Plate I, figs. 1, 3-5).

\section{A.2.8. Paratypes}

CAS slide number 22,028, sample NH01-21, 16$17 \mathrm{~cm}$ (Plate I, figs. 7-9, Plate II, fig. 1); CAS slide number 22029, sample BAM 80 E-17, 25-26 cm (Plate 2, fig. 2); CAS slide number 22,030, sample BAM80 E-17, 95-96 cm (Plate II, fig. 3); CAS accession number 625084, sample NH01-26, 57-58 cm (Plate II, figs. 4, 5).

\section{A.2.9. Type locality}

Southern Gulf of California core NH01-26, 15-16 cm, $24^{\circ} 16.78^{\prime} \mathrm{N}, 108^{\circ} 11.65^{\prime} \mathrm{W}$, water depth of $600 \mathrm{~m}$.

\section{A.3. Other silicoflagellates}

D. aculeata (Lemmermann) Dumitrica, 1973; D. epiodon of Murray and Schrader, 1983, pl. I, figs. 7-12; D. mandrai of Schrader et al., 1986. Schrader et al. (1986) associate it with the eastern equatorial Pacific and with California Current and suggest that its occurrence in the Gulf is due to oceanographic conditions that flush tropical waters into the Gulf. Barron et al. (2005) pl. I, figs. 3, 4.

Dictyocha sp. aff. D. aculeata (Lemmermann) Dumitrica, 1973. This large, robust silicoflagellate was illustrated by Barron et al. (2005, pl. I, figs. 1, 2; 5, 6; pl. II, figs. 1-5) from the JPC56 core in the central Gulf. The consistent large size (maximum length 60$70 \mu \mathrm{m}$, ring $40-50 \mu \mathrm{m}$ ) and polymorphic character of this taxon contrasts with the smaller, more typical $D$. aculeata forms in the Gulf. Although a few of the specimens resemble oceanic $D$. aculeata by the cant of the apical bar and eight basal ring apices, the typical distinct basal pikes and linear surface texture of $D$. aculeata are missing. The Gulf specimens of $D$. sp. aff. $D$. aculeata resemble some specimens illustrated as $D$. sp. aff. D. aculeata from tropical Pacific site DSDP 425 (Bukry, 1980, p. 552, pl.1, figs. 5-7). The compared specimens at DSDP 425 have large exposed basal ring pikes like $D$. aculeata, a feature missing on the Gulf forms.

D. calida calida Poelchau, 1976. Schrader et al. (1986) associate it with the eastern equatorial Pacific and suggest that its occurrence in the Gulf is due to oceanographic conditions that flush surface waters out of the Gulf. Penetrates up the eastern margin.

D. calida ampliata Bukry, 1979, p. 982, pl. 2, figs. 1, 2,9 .
D. perlaevis Frenguelli, 1951; D. sp. B of Murray and Schrader, 1983, pl. II, figs. 6-10; D. fibula var. robusta (nomen nudum) of Schrader et al., 1986. Schrader et al. (1986) associate it with oligotrophic nutrient-depleted conditions, particularly in the central and northern Gulf.

D. perlaevis (elongate form); D. sp. A of Murray and Schrader, 1983, pl. II, figs. 1-5; D. californica (nomen nudum) of Schrader et al., 1986. Schrader et al. (1986) associate it with the Costa Rica Counter Current and suggest that its occurrence in the Gulf is due to oceanographic conditions that flush surface waters out of the Gulf.

D. stapedia Haeckel, 1887; D. messanenesis of Murray and Schrader, 1983, pl. I, figs. 13-19 and of Schrader et al., 1986. Schrader et al. (1986) associate it with oligotrophic nutrient-depleted conditions.

O. pulchra Schiller, 1925, Murray and Schrader, 1983, Pl. I, figs. 1-6; Distephanus pulchra of Schrader et al., 1986. Schrader et al. (1986) note that it is most common in nutrient-rich upwelling regions.

\section{Appendix B. Supplementary data}

Supplementary data associated with this article can be found, in the online version, at doi:10.1016/j. marmicro.2006.08.003.

\section{References}

Bandon-Dangon, A., Dorman, C.E., Merrifield, M.A., Wianat, C.D., 1991. The lower atmosphere over the Gulf of California. J. Geophys. Res. 96 (C9), 16,877-16,896.

Barron, J.A., Bukry, D., Bischoff, J.L., 2003. A 2000-yr-long record of climate from the Gulf of California. In: West, G.J., Blomquist, N.L. (Eds.), Proceedings of the 19th PACLIM Workshop, Asilomar, CA, March 3-6, 2002, Technical Report 71 of the Interagency Ecological Program for the San Francisco Estuary, pp. 11-21.

Barron, J.A., Bukry, D., Bischoff, J.L., 2004. High resolution paleoceanography of the Guaymas Basin, Gulf of California, during the past 15,000 years. Mar. Micropaleontol. 50 (3-4), 185-207.

Barron, J.A., Bukry, D., Dean, W.E., 2005. Paleoceanographic history of the Guaymas Basin, Gulf of California, during the past 15,000 years, based on diatoms, silicoflagellates, and biogenic sediments. Mar. Micropaleontol. 56, 81-102.

Baumgartner, T.R., Christensen, N., 1985. Coupling of the Gulf of California to large-scale interannual climatic variability. J. Mar. Res. 43, 825-848.

Bema, J.M., Arrigo, K.R., Matson, P.A., 2005. Agricultural runoff fuels large phytoplankton blooms in vulnerable areas of the ocean. Nature 434, 211-214.

Bukry, D., 1979. Comments on opal phytoliths and stratigraphy of Neogene silicoflagellates and coccoliths at Deep Sea Drilling Project, Site 397 off northwest Africa. In: Luyendyk, B.P., Cann, J.R. (Eds.), Initial Repts., DSDP, vol. 49, pp. 977-1009.

Bukry, D., 1980. Silicoflagellate biostratigraphy and paleoecology in the eastern Pacific Ocean, Deep Sea Drilling Project Leg 54. In: t1Rosendahl, B.R., Hekinian, R. (Eds.), Initial Repts., DSDP, vol. 54, pp. $545-573$. 
Damon, P.E., Sonnett, C.P., 1991. Solar and terrestrial components of the atmospheric ${ }^{14} \mathrm{C}$ variation spectrum. In: Sonnett, C.P., Giampapa, M.S., Matthews, M.S. (Eds.), The Sun in Time. The University of Arizona Press, Tucson, AZ, pp. 360-388.

Dean, W., Pride, C., Thunell, R., 2004. Geochemical cycles in sediments deposited on the slopes of the Guaymas and Carmen Basins of the Gulf of California over the last 180 years. Quat. Sci. Rev. 23, 1817-1833.

Douglas, R.G., Gonzalez-Yajimovich, O., Ledesma-Vazquez, J., Staines-Urias, F., in press. Climate forcing, primary production and the distribution of Holocene biogenic sediments in the Gulf of California. Quat, Sci. Rev.

Frantz, B.R., Kashgarian, M., Coale, K.H., Foster, M.S., 2000. Growth rate and potential climate record from a rhodolith using ${ }^{14} \mathrm{C}$ accelerator mass spectrometry. Limnol. Oceanogr. 45, $1773-1777$.

Goñi, M.A., Hartz, D.M., Thunell, R.C., Tappa, E., 2001. Oceanographic considerations in the application of the alkenone-based paleotemperature $\mathrm{U}^{\mathrm{k}} 37$ index in the Gulf of California. Geochim. Cosmochim. Acta 65, 545-557.

Goñi, M.A., Thunell, R.C., Woodsworth, M.P., Müller-Karger, in press. Changes in wind-driven upwelling during the last three centuries: Interocean teleconnections. Geophys. Res. Lett.

Herguera, J.C., Franco, G.B., Molina-Cruz, A.C., 2003. Decadal surface ocean variability in the lower Gulf of California: records for the past 300 years. Geofís. Int. 42 (3), 397-406.

Julliet-Leclerc, A., Schrader, H.J., 1987. Variations of upwelling intensity recorded in varved sediment from the Gulf of California during the past 3000 years. Nature 329, 146-149.

Kahru, Mati, Marinone, S.G., Lluc-Cota, S.E., Parés-Sierra, Aldjandrao, Mitchell, B.G., 2004. Ocean color variability in the Gulf of California: scales from days to ENSO. Deep-Sea Res., Part 2, Top. Stud. Oceanogr. 51, 139-146.

Karlin, R., 1984. Paleomagnetism, Rock Magnetism and Diagenesis in Hemipelagic Sediments from the Northeast Pacific Ocean and the Gulf of California. Ph.D. Thesis, Oregon State University, Corvallis, Oregon, $246 \mathrm{pp}$.

Kemp, A.E.S., Pike, J., Pearce, R.B., Lange, C., 2000. The "Fall dump" - a new perspective on the role of a "shade flora" in the annual cycle of diatom production and export flux. Deep-Sea Res., Part 2, Top. Stud. Oceanogr. 47, 2129-2154.

Lavîn, M.F., Palacios-Hernández, E., Cabrera, C., 2002. Sea surface temperature anomalies in the Gulf of California. Geofís. Int. 43 (3), 363-375.

Le, G.-M., Wang, J.-L., 2003. Wavelet analysis of several important periodic properties in the relative sunspot numbers. Chin. J. Astron. Astrophys. 3 (5), 391-394.

MacDonald, G.M., Case, R.A., 2005. Variations in the Pacific Decadal Oscillation over the past millennium. Geophys. Res. Lett. 32, LO8703.

Marinone, S.G., 2003. A three-dimensional model of the mean and seasonal circulation of the Gulf of California. J. Geophys. Res. 108 (C10), 3325. doi:10.1029/2002JC001720.

Mitchell, D.L., Ivanova, D., Rabin, R., Redmond, K., Brown, T.J., 2002. Gulf of California sea surface temperatures and the North American monsoon: mechanistic implications from observations. J. Climate 15, 2261-2281.

Murray, D., 1982. Paleo-oceanography of the Gulf of California Based on Silicoflagellates from Marine Varved Sediments. M.S. Thesis, Oregon State University, Corvallis, Oregon, 129 pp.

Murray, D., Schrader, H.J., 1983. Distribution of silicoflagellates in plankton samples from the Gulf of California. Mar. Micropaleontol. $7,517-539$.
Pares-Sierra, A., Mascarenhas, A., Marinone, S.G., Castro, R., 2002. Temporal and spatial variation of surface winds in the Gulf of California. Geophys. Res. Lett. 30 (6), 1312.

Pike, J., Kemp, A.E.S., 1997. Early Holocene decadal-scale ocean variability recorded in Gulf of California laminated sediments. Paleoceanography 12 (2), 227-238.

Poelchau, H.S., 1976. Distribution of Holocene silicoflagellates in North Pacific sediments. Micropaleontology 22 (2), 164-193.

Poore, R.Z., Quinn, T.M., Verardo, S., 2004. Century-scale movement of the Atlantic Intertropical Convergence Zone linked to solar variability. Geophys. Res. Lett. 31, L12214.

Sancetta, C., 1995. Diatoms in the Gulf of California: seasonal flux patterns and the sediment record for the last 15,000 years. Paleoceanography 10 (1), 67-84.

Santamaria-del-Angel, E., Alavrez-Borrego, S., Muller-Karger, F.E., 1994. Gulf of California biogeographic regions based on coastal zone color scanner imagery. J. Geophys. Res. 99 (C4), 7411-7421.

Schrader, H.-J., Gersonde, R., 1978. Diatoms and silicoflagellates. In: Zachariasse, W.J., et al. (Eds.). Micropaleontological counting methods and techniques - an Exercise of an eight metres section of the lower Pliocene of Cap Rossello, Sicily, Utrecht Micropaleontology Bulletin, vol. 17, pp. 129-176.

Schrader, H., Baumgartner, T., 1983. Decadal variation of upwelling in the central Gulf of California. In: Thiede, J., Suess, E. (Eds.), Coastal Upwelling Part 2. Plenum Publishing Corporation, New York, NY, pp. 247-276.

Schrader, H., Pisias, N., Cheng, G., 1986. Seasonal variation of silicoflagellates in phytoplankton and varved sediments in the Gulf of California. Mar. Micropaleontol. 10, 207-233.

Shindell, D.T., Schmidt, G.A., Mann, M.E., Rind, D., Waple, A., 2001. Solar forcing of regional climate change during the Maunder Minimum. Science 294, 2149-2152.

Soto-Mardones, L., Marinone, S.G., Pares-Sierra, A., 1999. Time and spatial variability of sea surface temperature in the Gulf of California. Cienc. Mar. 25 (1), 1-30.

Staines-Urias, F., Douglas, R.G., in press. Climatic-related variations in $\delta^{13} \mathrm{C}$ and $\delta^{18} \mathrm{O}$ in benthic and planktic foraminifera from the Gulf of California, In: Proceedings of the 21st. PACLIM Workshop, Asilomar, CA.

Stuiver, P.J., Bard, E., Beck, J.W., Burr, G.S., Hughen, K.A., Kromer, B., McCormac, F.G., Plicht, J., Spurk, M., 1998. INTCAL98 radiocarbon age calibration $24,000-0$ cal B.P. Radiocarbon 40 , 1041-1083.

Thunell, R.C., 1998. Seasonal and annual variability in particle fluxes in the Gulf of California: a response to climate forcing. Deep-Sea Res., Part 1, Oceanogr. Res. Pap. 45, 2059-2083.

Thunell, R.C., Pride, C., Tappa, E., Muller-Karger, F., 1994. Varve formation in the Gulf of California: insights from time series sediment trap and remote sensing. Quat. Sci. Rev. 12, 451-464.

Thunell, R.C., Pride, C., Ziveri, P., Muller-Karger, F., Sancetta, C., Murray, D., 1996. Plankton response to physical forcing in the Gulf of California. J. Plankton Res. 18, 2017-2026.

Torrance, C., Campo, G.P., 1998. A practical guide to wavelet analysis. Bull. Am. Meteorol. Soc. 79, 61-78.

Wang, B., Wang, Y., 1999. Dynamics of the intertropical convergence zone-cold SST tongue complex. J. Climate 12, 1830-1847.

Zhang, Y., Wallace, J.M., Battisti, D.S., 1997. ENSO-like interdecadal variability: 1900-93. J. Climate 10, 1004-1020. 